\title{
Thermal and compressional behavior of the natural borate kurnakovite,
} $3 \mathrm{MgB}_{3} \mathrm{O}_{3}(\mathrm{OH})_{5} \cdot \mathbf{5} \mathrm{H}_{2} \mathrm{O}$

4 Francesco Pagliaro ${ }^{\mathrm{a}}$, Paolo Lotti ${ }^{\mathrm{a}}$, Tommaso Battiston ${ }^{\mathrm{a}}$, Davide Comboni ${ }^{\mathrm{a}, \mathrm{b}}$, G. Diego Gatta ${ }^{\mathrm{a}}$, 5 Fernando Cámara $^{\mathrm{a}}$, Sula Milani ${ }^{\mathrm{a}}$, Marco Merlini ${ }^{\mathrm{a}}$, Konstantin Glazyrin ${ }^{\mathrm{c}}$, Hanns-Peter Liermann ${ }^{\mathrm{c}}$

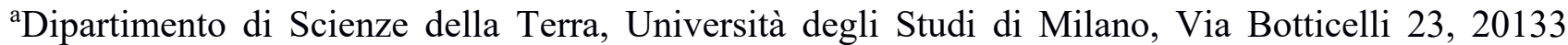

7 Milano, Italy

beuropean Synchrotron Radiation Facility, 71 Avenue des Martyrs, CS40220, 38043 Grenoble Cedex, France

'Photon Sciences, DESY, PETRA-III, Notkestrasse 85, 22607, Hamburg, Germany

* Corresponding Author: paolo.lotti@unimi.it; Tel: +39-02-50315601; Fax: +39-02-50315598

\section{Abstract}

The thermal and compressional behaviors of kurnakovite, a potential B-rich aggregate in neutron radiation-shielding concretes, were studied by in situ single-crystal synchrotron X-ray diffraction (100-393 K, 0-13.36(5) GPa). Above $393 \mathrm{~K}$, the crystal structure collapses in response to dehydration. The bulk thermal expansion coefficient is $\alpha_{V(298 \mathrm{~K})}=5.18(1) \cdot 10^{-5} \mathrm{~K}^{-1}$. Volume compressional trend modelled with a Birch-Murnaghan equation of state yields a bulk modulus of $K_{P 0, T O}=35(3) \mathrm{GPa}$. A phase transition occurs between 9.23(5) and 11.11(5) GPa, leading to a triclinic high- $P$ polymorph (with triple unit-cell volume) and to an increase in coordination of one third of the trigonal-planar boron sites to a tetrahedral geometry.

Keywords: Kurnakovite, borates, single-crystal diffraction, B-rich aggregate, high temperature, high pressure

\section{Introduction}

Natural borates represent the main source for boron, an element used in a variety of different industrial sectors, including glass, ceramics, electronics, metallurgy, textile, cosmetics and chemistry [1]. Boron, mainly in the form of borates and carbides, also finds applications as a fundamental constituent of neutron radiation-shielding materials, which are used in nuclear energy plants, as well as in facilities for scientific research or medical applications, e.g. [2-3]. The high capability of borates to act as neutron-shielding materials is due to the isotope ${ }^{10} \mathrm{~B}$, which represents about $20 \%$ of natural boron [4] and has a high cross section for thermal neutrons ( $\sim 3840$ barns [5]), leading to the following reaction:

$$
{ }^{10} \mathrm{~B}+\mathrm{n} \rightarrow \alpha+{ }^{7} \mathrm{Li}+\gamma
$$

According to the reaction above, compounds containing boron represent ideal materials to be added as aggregates in the production of radiation-shielding concretes. Synthetic $\mathrm{B}_{4} \mathrm{C}$, for example, proved to be efficiently adopted in this field [6] but, due to the high costs of synthesis, the use of the cheaper natural borates is preferred [7]. Moreover, hydrous borates, due to the capability of hydrogen to act as a neutron acceptor, improve the neutron-shielding efficiency of the material. Recently, a study on neutron permeability of natural borates has been conducted on inyoite, inderite, borax, kurnakovite and colemanite [8]. Kurnakovite has been identified as the most effective natural borate in neutron absorption [8]. Kurnakovite is a complex hydrous magnesium borate mineral, with an ideal chemical formula of $\mathrm{MgB}_{3} \mathrm{O}_{3}(\mathrm{OH})_{5} \cdot 5 \mathrm{H}_{2} \mathrm{O}$, with $\mathrm{B}_{2} \mathrm{O}_{3} \approx 37 \mathrm{wt} \%$ and $\mathrm{H}_{2} \mathrm{O} \approx 48 \mathrm{wt} \%$. Unlike the Na-bearing 
minerals borax $\left[\mathrm{Na}_{2} \mathrm{~B}_{4} \mathrm{O}_{5}(\mathrm{OH})_{4} \cdot 8 \mathrm{H}_{2} \mathrm{O}\right]$ and ulexite $\left[\mathrm{NaCaB}_{5} \mathrm{O}_{6}(\mathrm{OH})_{6} \cdot 5 \mathrm{H}_{2} \mathrm{O}\right]$, which have already been investigated for the application as B-rich aggregates in concretes (e.g. Glinicki et al. [2]), the Na-free kurnakovite cannot release this element, which is well known to promote deleterious reactions (i.e. Alcali-Silica Reactions, ASR) decreasing the durability and the mechanical strength of Portland cements.

Evaporitic sediments and rocks, emplaced in continental lacustrine settings in arid and semiarid environments, are the most common hosts for high-grade boron deposits. Whereas borax, colemanite, ulexite and kernite represent the most diffuse borates of economic importance [9], kurnakovite may also constitute a relevant fraction of the mineralization. For example, kurnakovite is well distributed in the Turkish deposit of Sarıaya [10-11] and in the Qinghai-Tibet Plateau deposits, where a Mgenrichment has been reported [12]. Kurnakovite forms for chemical precipitation processes in saltlake deposits, within brines enriched in magnesium and boron, or for secondary alteration of other Mg-bearing hydrous borates [12-14].

In this light, this study aims at investigating the behavior of natural kurnakovite at varying temperature (i.e., above and below the ambient $T$ ) and at high pressure, by means of in situ single-crystal synchrotron X-ray diffraction. The results will provide thermo-elastic parameters (bulk thermal expansion and compressibility coefficients), to be included in the thermodynamic databases, as well as a description of the thermo-elastic anisotropy, along with the mechanisms, at the atomic scale, that govern that. The phase stability fields of kurnakovite as a function of $T$ and $P$ will also be reported. In terms of potential applications of this mineral as aggregate in radiation-shielding concretes, due to its hydrous nature, the thermal stability is of a significant relevance, as a $T$-induced dehydration is expected to undermine the durability of the final products. This work is part of a long-term project devoted to characterize the crystal chemistry and explore the $T$ - and $P$-behaviors and stability of synthetic B-compounds [15] and natural hydrous borates [16- 21].

\subsection{Crystal structure of kurnakovite}

Kurnakovite is a member of the inderite group, commonly found in saline lake sediments along with borax and ulexite [22], which was first discovered at the Inder deposit (Kazakhstan). The chemical composition of kurnakovite has been first reported by Godlevsky [23] and, along with inderite, it is one of the two polymorphs of the compound $\mathrm{MgB}_{3} \mathrm{O}_{3}(\mathrm{OH})_{5} \cdot 5 \mathrm{H}_{2} \mathrm{O}$ [24]. Differences between the crystal structures of kurnakovite and inderite have been described by Corazza [25] and recently reported, on the basis of ${ }^{11} \mathrm{~B}$ and ${ }^{25} \mathrm{Mg} \mathrm{NMR}$, by Zhou et al. [26]: both inderite and kurnakovite have a crystal structure composed by $\mathrm{Mg}\left(\mathrm{H}_{2} \mathrm{O}\right)_{4} \mathrm{~B}_{3} \mathrm{O}_{3}(\mathrm{OH})_{5}$ electroneutral units and "zeolitic" $\mathrm{H}_{2} \mathrm{O}$ molecules. Inderite has a monoclinic unit-cell (space group $P 2_{1} / c$ ) and the $\mathrm{Mg}\left(\mathrm{H}_{2} \mathrm{O}\right)_{4} \mathrm{~B}_{3} \mathrm{O}_{3}(\mathrm{OH})_{5}$-units are organized in independent groups, whereas kurnakovite has a triclinic unit-cell (space group $P \overline{1}$ ) and its structure is characterized by the presence of chains. The first structural information about kurnakovite were given by Petch et al. [27] and later the crystal structure was solved by Razmanova et al. [28] and refined by Corazza [29], by means of single-crystal X-ray diffraction data collected with a Weissenberg camera. Recently, Gatta et al. [19], using single-crystal neutron diffraction data, provided a full anisotropic structural refinement, including even all the $\mathrm{H}$ atoms, and a comprehensive chemical analysis, by means of a multi-methodological approach, which surveyed the presence of 50 chemical elements, yielding a composition of the studied compound very close to the kurnakovite nominal formula. According to the model refined by Corazza [29] and later confirmed by Gatta et al. [19], the neutral $\mathrm{Mg}\left(\mathrm{H}_{2} \mathrm{O}\right)_{4} \mathrm{~B}_{3} \mathrm{O}_{3}(\mathrm{OH})_{5}$-units are organized in chains running along the [001] direction (Fig. 1). Every chain is made by the alternation of $\mathrm{Mg}(\mathrm{OH})_{2}\left(\mathrm{H}_{2} \mathrm{O}\right)_{4}$ octahedra and 3-membered rings of B-polyhedra, which are characterized by one $\left[\mathrm{BO}_{2}(\mathrm{OH})\right]$-group in trigonal-planar coordination and two $\left[\mathrm{BO}_{2}(\mathrm{OH})_{2}\right]$-tetrahedra (Fig. 1). Kurnakovite exhibits hydroxyl groups, cation-coordinated $\mathrm{H}_{2} \mathrm{O}$ and even loosely-bonded "zeolitic" $\mathrm{H}_{2} \mathrm{O}$ molecules, which are hydrogen-bonded to the $\mathrm{Mg}\left(\mathrm{H}_{2} \mathrm{O}\right)_{4} \mathrm{~B}_{3} \mathrm{O}_{3}(\mathrm{OH})_{5}$-units and populate the cavities confined by the chain system (Figs. 1 and 2). 


\section{Materials and experimental methods}

The crystals used in this study are from the same natural sample of kurnakovite previously studied by Gatta et al. [19]. This sample was provided by the Museum of Mineralogy of the University of Padova (Italy) and comes from the Kramer Deposit, Mohave Desert (Kern County, California, USA). A comprehensive description of the geological setting in which the samples were collected is reported by Noble [30], Siefke [31], Obert \& Long [32]. The chemical composition of the investigated samples of kurnakovite, determined on the basis of a multi-methodological approach, is $\mathrm{Mg}_{0.99}\left(\mathrm{Si}_{0.01} \mathrm{~B}_{3.00}\right)_{53.01} \mathrm{O}_{3.00}(\mathrm{OH})_{5} \cdot 4.98 \mathrm{H}_{2} \mathrm{O}$, showing an almost perfect agreement with the nominal chemical formula of this mineral. Further details on the experimental protocol for the chemical analysis are reported by Gatta et al. [19].

\subsection{Low-temperature and high-temperature X-ray diffraction experiments}

In situ low-temperature (i.e. $T<298 \mathrm{~K})$ and high-temperature $(T>298 \mathrm{~K})$ synchrotron single-crystal X-ray diffraction experiments were performed at the XRD1 beamline of the Elettra facility (Trieste, Italy). A single crystal of kurnakovite $\left(80 \times 60 \times 50 \mu \mathrm{m}^{3}\right)$ was loaded in a quartz capillary $(100 \mu \mathrm{m}$ in diameter $)$. A monochromatic and polarized incident X-ray beam, with energy of $17.71 \mathrm{keV}(\lambda=0.700$ $\AA$ ), was used. Low-temperature conditions were obtained by means of an Oxford Cryostream 700 cryostat, which provided a continuum cold nitrogen flux on the quartz capillary holding the sample. A first ramp from $100 \mathrm{~K}$ to ambient temperature $(298 \mathrm{~K})$, with data collections every $20 \mathrm{~K}$, was performed. A second ramp, at high-temperature conditions, was performed by heating the sample via a hot gas blower (DGB-0002). The high-temperature ramp ranges from $353 \mathrm{~K}$ to $423 \mathrm{~K}$, with data collections every $20 \mathrm{~K}$. Temperature was measured by a thermocouple, previously calibrated using the thermal expansion of quartz. The X-ray diffraction patterns were collected by a Dectris Pilatus $2 \mathrm{M}$ detector. The detector-sample distance was $100.05 \mathrm{~mm}$ for the low-temperature ramp and $395.28 \mathrm{~mm}$ for the high-temperature one. The two sample-detector distances have been calculated using a standard NIST 640e Si powder as calibrant. Data collections at low- and high-temperature were performed adopting the same strategy: each data collection is composed by a step-wise $360^{\circ}$ rotation along $\varphi$ $\left(\chi=90^{\circ}\right)$, according to the 4-circle Eulerian geometry, with a step-width of $1^{\circ}$ and an exposure time of $1 \mathrm{~s} /$ frame.

For both low- and high- $T$ experiments, indexing of the diffraction peaks, unit-cell parameters refinement and intensity data reduction were performed using the CrysAlisPro software [33].

\subsection{High-pressure X-ray diffraction experiments}

In situ high-pressure (at ambient temperature, $297 \mathrm{~K}$ ) single-crystal synchrotron X-ray diffraction experiments were performed at the Extreme Conditions Beamline P02.2 at DESY/PETRA-III (Hamburg, Germany). A monochromatic incident X-ray beam with an energy of $42.8 \mathrm{keV}(\lambda=0.2898$ $\AA$ ) was used. A diamond anvil cell (DAC), equipped with Boehler-Almax designed diamonds/seats with $60^{\circ}$ opening and $300 \mu \mathrm{m}$ culets size, was used to generate quasi-hydrostatic pressure. A $250 \mu \mathrm{m}-$ thick rhenium foil gasket was pre-indented to $60 \mu \mathrm{m}$ and then drilled by spark erosion, to obtain a cylindrical pressure chamber, $150 \mu \mathrm{m}$ in diameter. A single crystal of kurnakovite $\left(20 \times 20 \times 15 \mu \mathrm{m}^{3}\right)$, along with a few ruby micro-spheres as pressure calibrants (pressure uncertainty $\pm 0.05 \mathrm{GPa}[34,35]$ ), were loaded in the pressure chamber. For each $P$-point, the same data collection strategy was used, consisting in a step-wise $\omega$-scan $\left(-30^{\circ}<\omega<+30^{\circ}\right)$ with a step-width of $0.5^{\circ}$ and an exposure time of $1 \mathrm{~s} /$ frame. At ambient conditions, the X-ray diffraction pattern was collected with the crystal loaded in the DAC without any $P$-transmitting fluid. Then, neon was used as quasi-hydrostatic pressuretransmitting fluid [36] and the pressure increase was controlled by an automated pressure-driven system. X-ray diffraction patterns were collected on a PerkinElmer 1621 XRD flat-panel detector, set at a distance of $395.38 \mathrm{~mm}$ from the sample. The sample-to-detector distance was calibrated using a $\mathrm{CeO}_{2}$ standard (NIST 674a). Experimental data were collected using an in-house script and then 
converted to the "Esperanto" format in order to be processed by the CrysAlisPro software [33, 37], for the indexing of the X-ray diffraction peaks, unit-cell refinements and intensity data reduction (corrected for Lorentz-polarization effects). Absorption effects, due to the DAC components, were corrected using the semi-empirical $A B S P A C K$ routine, implemented in CrysAlisPro.

\subsection{Structure refinements}

The experimental X-ray diffraction patterns collected at ambient conditions were compatible with the space group $P \overline{1}$ and the unit-cell parameters of kurnakovite reported by Corazza [29].

All structure refinements were performed using the software Jana2006 [38], starting from the model reported by Gatta et al. [19] in the space group $P \overline{1}$. On the basis of the reported chemical purity of the investigated sample [19], all the crystallographic sites were modelled as fully occupied, using the $\mathrm{Mg}$, $\mathrm{B}$ and $\mathrm{O}$ neutral scattering curves [39]. For the high-pressure data, in order to reduce the number of refined variables, the atomic displacement parameters (ADP) were all refined as isotropic. Due to the reciprocal lattice coverage limitations induced by the limited opening angle in the DAC, an $\mathrm{H}$-free structure model was used for all the high- $P$ refinements. The atomic fractional coordinates and ADP parameters refined from three selected datasets of kurnakovite $\left(P_{\mathrm{amb}}, 4.43(5)\right.$ and 8.08(5) GPa) and one (at 11.11(5) GPa) of kurnakovite-II, the HP polymorph (see section 3.3 for further details), are reported in Tab. 1 and Tab. 2, respectively. The structure refinements based on the HT and LT data were performed adopting anisotropic displacement parameters, except for the H-atoms (for which displacement parameters were kept constant, with $U_{\text {iso }}=0.037 \AA^{2}$ ), and refining the extinction factor by means of an anisotropic model. The refined atomic fractional coordinates and ADPs at three different temperature conditions $(100,297$ and $393 \mathrm{~K})$ are reported in Tab. 3 and Tab. S1 (supplementary materials), respectively. All the refinements converged with no significant correlations among the refined variables. A selection of relevant statistical parameters pertaining to the structure refinements at $\mathrm{H} P, \mathrm{H} T$ and $\mathrm{L} T$ is reported in Tab. 4. The results of all the structure refinements are deposited as Supplementary materials (CIF files).

\section{Results and discussion}

\subsection{Thermal behavior and dehydration}

The evolution of the unit-cell parameters of kurnakovite with $T$ shows that no phase transition occurs in the $T$-range investigated, up to the complete amorphization of kurnakovite observed at a temperature higher than $393 \mathrm{~K}$ (Tab. 5, Fig. 3). At this temperature, the diffraction pattern can still be indexed, but more than $90 \%$ of the X-ray diffraction peaks are lost; at $423 \mathrm{~K}$ no discrete reflections in the X-ray diffraction pattern are observed. The (X-ray)-amorphization temperature of kurnakovite shows a good agreement with a previous HT-study conducted by means of thermogravimetric (TG) analysis coupled with DTA, which reports a strong dehydration peak at ca. $412 \mathrm{~K}$ [8]. The weight loss measured by Derun \& Kipcak [8], $44.58 \%$, is very close to the total fraction of $\mathrm{H}_{2} \mathrm{O}$ determined by Gatta et al. [19] for the same sample of kurnakovite investigated in this study (48.2(2) wt \%). Tab. 5 and Fig. 3 report the evolution of the unit-cell parameters with temperature, showing an anisotropic thermo-elastic behavior. The unit-cell edge parallel to [010] shows the minor variation, especially below the ambient temperature. The bulk thermal expansion is substantially accommodated along the $a$ and $c$ unit-cell axes, which both show a similar thermal expansivity in the investigated $T$-range (Fig. 3 ).

In order to model the bulk thermal expansion of kurnakovite, a modified version of the equation of state of Pawley et al. [40], reported by Holland \& Powell [41], was fitted to the experimental $V-T$ data, using the Eos_Fit7c software $[42,43]$. The adopted equation of state is expressed as:

$$
V_{T}=V_{0}\left(1+\alpha_{0}\left(T-T_{r e f}\right)-2\left(10 \alpha_{0}+\alpha_{1}\right)\left(\sqrt{T}-\sqrt{T_{\text {ref }}}\right)\right)
$$


where $T_{\text {ref }}=298 \mathrm{~K}, V_{0}$ is the unit-cell volume at $T_{\text {ref }}$ and $\alpha_{0}$ and $\alpha_{1}$ are refinable parameters.

The fit to the experimental data yields the following refined parameters: $\alpha_{0}=12.9(3) \cdot 10^{-5} \mathrm{~K}^{-1}, \alpha_{1}=$ $2.2(2) \cdot 10^{-4} \mathrm{~K}^{-1 / 2}$ and $V_{0}=500.51(2) \AA^{3}$. The calculated bulk thermal expansion coefficient at ambient conditions is $\alpha_{V(298 \mathrm{~K})}=5.18(1) \cdot 10^{-5} \mathrm{~K}^{-1}$. The mean thermal expansivity values along the axes of the unit-strain ellipsoid have been determined between 100 and $393 \mathrm{~K}$, using the Win_Strain software [44], showing a dramatic thermal anisotropy: $\alpha_{1}=3.7(1) \cdot 10^{-5} \mathrm{~K}^{-1}, \alpha_{2}=1.8(1) \cdot 10^{-5} \mathrm{~K}^{-1}$ and $\alpha_{3}=$ $0.10(5) \cdot 10^{-5} \mathrm{~K}^{-1}$. The geometrical relationships between the unit-strain ellipsoid and the crystallographic axes are described by the following matrix:

$$
\left(\begin{array}{l}
\alpha_{1} \\
\alpha_{2} \\
\alpha_{3}
\end{array}\right)=\left(\begin{array}{ccc}
59.2(5)^{\circ} & 71.2(4)^{\circ} & 68.4(8)^{\circ} \\
40.9(9)^{\circ} & 93.4(7)^{\circ} & 150(1)^{\circ} \\
65.8(6)^{\circ} & 160.9(3)^{\circ} & 70.0(8)^{\circ}
\end{array}\right) \cdot\left(\begin{array}{l}
a \\
b \\
c
\end{array}\right)
$$

which agrees with the low thermal expansivity shown by the $b$ unit-cell parameter (Fig. 3 and Tab. 5), given the $19.1(3)^{\circ}$ angle between $\alpha_{3}$ and [0필.

The structure refinements based on the XRD data collected at different $T$ conditions do not show any significant structural re-arrangement between 100 and $393 \mathrm{~K}$, nor a change in the H-bonding configuration. Analysis of the $T$-induced evolution of the interatomic distances between the oxygen donors (D) and acceptors (A) (Tab. S2) shows that, with few exceptions, the D-A distances expand with increasing temperature. This behavior suggests that the collapse of the H-bonding network plays a key role in triggering the amorphization of kurnakovite at $T>393 \mathrm{~K}$, similarly to the behavior shown in colemanite, for which the amorphization occurs in the very early stages of dehydration at $T>513$ $\mathrm{K}[18]$.

\subsection{High-pressure behavior}

The high-pressure evolution of the unit-cell parameters is shown in Tab. 6 and Fig. 4. The ambientconditions polymorph of kurnakovite is found to be stable up to 9.23(5) GPa. Above this pressure, a phase transition to a high-pressure polymorph, which will be discussed in the next section, occurs. A Birch-Murnaghan Equation of State truncated to the third order (BM3-EoS) $[45,46]$ was fitted to the experimental $P-V$ data of the ambient-conditions polymorph, using the Eos_Fit7c software [43]. The $\mathrm{BM}-\mathrm{EoS}$ is an isothermal equation of state based on the assumption that the high-pressure strain energy of a solid can be expressed as a Taylor series in the Eulerian finite strain, defined as $f e=$ $\left[\left(V_{0} / V\right)^{2 / 3}-1\right] / 2$. This equation of state allows to refine the bulk modulus $\left(K \mathrm{P} 0, \mathrm{~T} 0=-V_{0}(\partial P / \partial V) \mathrm{T} 0=\beta^{-}\right.$ ${ }_{\mathrm{P} 0, \mathrm{~T} 0 \text {, where } \beta \mathrm{P} 0, \mathrm{~T} 0}$ is the volume compressibility coefficient at ambient conditions) and its $P$ derivatives. When truncated to the third order, the BM3-EoS is expressed as:

$$
P(f e)=3 K_{\mathrm{P} 0, \mathrm{~T} 0} f e(1+2 f e)^{5 / 2}\left[1+3 / 2\left(K^{\prime}-4\right) f e\right],
$$

where $K^{\prime}=\partial K_{\mathrm{P} 0, \mathrm{~T} 0} / \partial P$.

The fit of the BM3-EoS to the experimental data yields the following refined parameters: $K_{\mathrm{P} 0, \mathrm{~T} 0}=35(3)$ $\mathrm{GPa}, K^{\prime}=6.3(1)$ and $V_{0}=498.8(2) \AA^{3}$

Fig. 4 shows that the elastic deformation of kurnakovite at high pressure is significantly anisotropic, with [010] being the most compressible crystallographic direction. The analysis of the finite Eulerian unit-strain tensor, performed using the software Win_Strain [44], allowed to calculate the mean compressibility values along the axes of the strain ellipsoid determined between 0.0001 and 9.23 GPa: $\varepsilon_{1}=0.00920(6) \mathrm{GPa}^{-1}, \varepsilon_{2}=0.00515(6) \mathrm{GPa}^{-1}, \varepsilon_{3}=0.00299(12) \mathrm{GPa}^{-1}$. The geometrical relationships between the strain ellipsoid and the crystallographic axes are described by the following matrix: 


$$
\left(\begin{array}{l}
\varepsilon_{1} \\
\varepsilon_{2} \\
\varepsilon_{3}
\end{array}\right)=\left(\begin{array}{ccc}
114.9(5)^{\circ} & 14.8(7)^{\circ} & 86.3(7)^{\circ} \\
72(2)^{\circ} & 76.8(5)^{\circ} & 176.2(6)^{\circ} \\
148(1)^{\circ} & 96.5(6)^{\circ} & 90(2)^{\circ}
\end{array}\right) \cdot\left(\begin{array}{l}
a \\
b \\
c
\end{array}\right)
$$

223 which shows that the most compressible direction almost coincides with the $b$ crystallographic axis, 224 given the low angle between them, i.e. 14.8(7).

Structure refinements of the ambient-conditions polymorph of kurnakovite, based on the XRD data collected between room- $P$ and 9.23(5) GPa, allowed to describe the structural mechanisms acting at the atomic scale which controls the bulk compression. Tab. S3 shows that the B coordination environments are substantially uncompressible, whereas the shortening of $\mathrm{Mg}$ - $\varphi$ bond distances $(\varphi=$ $\mathrm{O}, \mathrm{OH}, \mathrm{OH}_{2}$ ) leads to the compression of the $\mathrm{Mg}$ coordination polyhedra (Tab. 7). A Birch-Murnaghan equation of state (truncated to the second order) was used to fit the $V_{\mathrm{Mg}}-P$ data (Tab. 7), using the $E o S \_F i t 7 c$ software [40], yielding the following refined bulk modulus for the Mg-polyhedron at ambient conditions: $K_{V \mathrm{Mg}}=73$ (4) GPa. The bulk volume compression is, therefore, accommodated by the $\mathrm{Mg}$ coordination polyhedra and by the tilting of the other structural units. Only a subtle structural re-arrangement is observed along the direction of the chains made by the $\mathrm{Mg}$ - and $\mathrm{B}$-polyhedra, as suggested by the evolution of the B1-Mg1-B1 angle (Figs. 2 and 4; Tab. 8), which shows a slight increase from $147.86(2)^{\circ}$ at atmospheric pressure to $149.2(2)^{\circ}$ at $9.23(5) \mathrm{GPa}$. The interchain structural re-arrangement is more pronounced, as suggested by the compression of the O12-O12-O12 angle (Figs. 2 and 4; Tab. 8), which reflects the $P$-induced "interpenetration" of adjacent chains, leading to a partial overlap of adjacent borate rings, along a direction almost parallel to the $b$ crystallographic axis, in agreement with magnitude and orientation of the unit-strain ellipsoid. Interestingly, a "non-inverse" behavior (sensu Hazen and Finger [47]) is not shown at varying temperature as seen in section 3.1. On the contrary, the $b$ crystallographic axis is the less affected by the thermal variation. The striking difference between the compressional and thermal behavior along the [010] direction is likely ascribable to the pervasive H-bonding network, which allows the compression through the "interpenetration" of adjacent chains, but may prevent the expansion due to an already stretched configuration of the H-bonds (Tab. S2). Unfortunately, due to the modest X-ray scattering power of $\mathrm{H}$-atoms and the limited reciprocal lattice coverage caused by the opening angle of the DAC, hydrogen sites cannot be included in the high- $P$ structure refinements, hindering a more detailed discussion on the role played by the H-bonding network (Fig. 2) on the high-pressure structural re-arrangement of kurnakovite.

\subsection{High-pressure phase transition}

As mentioned above, between 9.23(5) and 11.11(5) GPa a single-crystal to single-crystal phase transition, reconstructive in character and with an increase of $\sim 3 \%$ in density, occurs without any change in the space group, which remains $P \overline{1}$. However, the high- $P$ polymorph, hereafter named kurnakovite-II, is characterized by the tripling of the unit-cell volume: the unit-cell parameters of kurnakovite-II at 11.11(5) GPa are the following: $a=11.012(2) \AA, b=10.827(2) \AA, c=11.286(2) \AA$, $\alpha=99.65(1)^{\circ}, \beta=93.96(2)^{\circ}, \gamma=112.45(2)^{\circ}$ and $V=1212.8(3) \AA^{3}$. The geometrical relationships between the unit cells of kurnakovite and kurnakovite-II are described by the following matrix:

$$
\left(\begin{array}{l}
a^{\prime} \\
b^{\prime} \\
c^{\prime}
\end{array}\right)=\left(\begin{array}{ccc}
-1 & -1 & 0 \\
0 & 1 & 1 \\
-1 & 0 & -2
\end{array}\right)\left(\begin{array}{l}
a \\
b \\
c
\end{array}\right)
$$

where $a^{\prime}, b^{\prime}$ and $c^{\prime}$ refer to kurnakovite-II, whereas $a, b$ and $c$ refer to kurnakovite. The unit-cell parameters of kurnakovite-II refined at 11.11(5), 12.21(5) and 13.63(5) GPa are reported in Tab. 6. Furthermore, the unit-cell parameters of kurnakovite-II can also be described in a different setting (according to the ambient-conditions polymorph geometry) given in Tab. S4. 
The kurnakovite-II crystal structure has been successfully solved using the SUPERFLIP suite [48] implemented in JANA2006, which allowed to locate most of the crystallographic sites. Then, after a series of least-squares refinements followed by difference-Fourier syntheses of the electron density, the location of the missing atoms was achieved. The tripling of the unit-cell volume implies the split of any independent atomic-sites of kurnakovite into three independent sites in kurnakovite-II: 3 independent magnesium, 9 boron and 39 oxygen sites.

From the structural point of view, the phase transition does not induce dramatic changes. The crystal structure can still be described by infinite chains of alternating Mg-polyhedra and 3-membered rings of B-polyhedra. Unfortunately, the inability to locate the $\mathrm{H}$ atoms prevents a robust discussion on the inter-chains connection via the H-bonding network. The tripling of independent sites of kurnakovite implies that, in the $\mathrm{H} P$-polymorph, the chains are characterized by the repetition of units made by three independent Mg-polyhedra and three independent borate rings, providing more degrees of freedom for a moderate intra-chain distortion with respect to kurnakovite (Fig. 5). The most significant consequence of the phase transition concerns one of the three B sites derived from the parent trigonalplanar B3. The B33 atom increases its coordination configuration from trigonal-planar to tetrahedral, by bonding with the $\mathrm{O} 43$ atom that belongs already to a $\mathrm{H}_{2} \mathrm{O}$ molecule in the coordination sphere of the $\mathrm{Mg} 13$ atom (Fig. 5). The formation of this new bond requires only a local distortion of the crystal structure, resulting in the preservation of the long-range order, as confirmed by the single-crystal to single-crystal nature of the phase transition. A similar behavior was also shown by colemanite $\left[\mathrm{CaB}_{3} \mathrm{O}_{4}(\mathrm{OH})_{3} \cdot \mathrm{H}_{2} \mathrm{O}\right]$, which underwent a $P 2{ }_{1} / a$-to- $P 2_{1} / a$ phase transition between 13.95 and 14.91 $\mathrm{GPa}$, with a unit-cell volume of the high- $P$ polymorph that is 6 times the low- $P$ one, and in which any parent crystallographic site generates six new independent sites [16]. Also in colemanite, a fraction of trigonal-planar $\mathrm{B}$ increases its coordination to tetrahedral by bonding to a $\mathrm{H}_{2} \mathrm{O}$-oxygen atom in colemanite-II; an increase in the coordination number of a fraction of the Ca sites was also observed. Similarly, kernite $\left[\mathrm{Na}_{2} \mathrm{~B}_{4} \mathrm{O}_{6}(\mathrm{OH})_{2} \cdot 3 \mathrm{H}_{2} \mathrm{O}\right]$, undergoes a $P 2_{1} / c$-to- $P 2_{1} / c$ phase transition, isosymmetric in character, between 1.6 and $2.0 \mathrm{GPa}$ [21], which involves an increase in the coordination number of the $\mathrm{Na}$ atoms, whereas no change in the coordination environments of $\mathrm{B}$ was observed. A second phase transition, apparently isosymmetric, was observed between 6.6 and $7.5 \mathrm{GPa}$, but any attempt to solve the crystal structure of kernite-III was unsuccessful [21].

When compared to the aforementioned borates, the phase transition shown by kurnakovite in this study is more closely related to that observed in colemanite, because of the very high pressures it occurs and due to the increase in the coordination number of a fraction of B sites from three to four. On the contrary, in the Na-bearing kernite, a $P$-induced phase transition occurs at lower pressure, involving only the coordination environment of the monovalent cation. These results shed a new light on the high-pressure behavior of B-bearing hydrous compounds, highlighting the potential role that monovalent or divalent cations can play.

Any discussion on the high- $P$ structure evolution of kurnakovite-II is hindered by the fact that, at the highest investigated pressure (13.63(5) GPa), a drastic reduction of "observed" peaks (i.e. with $I_{h k l} \geq$ $\left.3 \sigma\left(I_{h k l}\right)\right)$ prevented any attempt of structure refinement. Data collected in decompression at $10.80(5)$ and 8.29(5) GPa allowed the indexing of the few diffraction peaks and the refinement of the unit-cell parameters (Tab. 6), which suggest a significant hysteresis of the transition; no structure refinement was performable. Interestingly, the data collected after decompression at ambient- $P$ (after full release of $P$ ) showed the absence of any diffraction pattern, indicating the irreversible nature of the phase transition and a structural collapse of kurnakovite-II upon full pressure release.

\section{Conclusions}


The present study allowed the characterization, for the first time, of the thermo-elastic behavior of kurnakovite, which could serve as a potential aggregate in neutron radiation-absorber concretes. Kurnakovite shows a significant thermal anisotropy with the bulk expansion being mainly accommodated along the $a$ and $c$ crystallographic directions. Under pressure, kurnakovite shows a similar anisotropic elastic behavior, but the direction of higher compressibility almost coincides with the $b$ crystallographic axis. The bulk thermal expansion coefficient and the bulk compressibility of kurnakovite at ambient conditions are provided along with their evolution as a function of temperature and pressure, respectively. Based on these data, we can provide a $P-V-T$ equation of state, valid at a first approximation:

$$
V(P, T)=V_{0}+5.18(1) \cdot 10^{-5 *}\left(T-T_{0}\right)-0.029(2) *\left(P-P_{0}\right)
$$

where $T_{0}$ and $P_{0}$ are $298 \mathrm{~K}$ and $0.0001 \mathrm{GPa}$, respectively, and $V_{0}$ the unit-cell volume at ambient conditions.

The XRD data obtained at high- $T$ in this study, in agreement with the previous TG and DTA data reported by Derun \& Kipcak [8], show that, due to the dehydration phenomena, the crystal structure of kurnakovite is unstable at $T>393 \mathrm{~K}$ and is completely amorphized at $423 \mathrm{~K}$. This behavior poses severe questions on the potential applicability of kurnakovite, as is, in radiation-shielding concretes. Despite several operating conditions do not reach temperatures higher than $\sim 373 \mathrm{~K}$ [i.e. $\sim 100{ }^{\circ} \mathrm{C}$; see e.g. Lotti et al. [18] and references therein], the observed structural degradation at $393 \mathrm{~K}$ would suggest to consider alternative neutron absorber minerals for any application which should sustain nonambient temperature conditions. In this context, one may consider the highest thermal stability of natural colemanite (at least up to $513 \mathrm{~K}$ [18]) as a suitable alternative. However, a transformation product (e.g. a dehydrated form) of kurnakovite could still be considered.

At high pressure, kurnakovite is stable under the conditions for any technical utilization. The $P$ induced structural re-arrangement of kurnakovite sheds a new light on the intriguing high-pressure behavior of hydrous natural borates. Kurnakovite undergoes a reconstructive phase transition between 9.23(5) and 11.11(5) GPa towards a polymorph, kurnakovite-II, still triclinic but with a unit-cell volume three times larger with respect to kurnakovite. As in colemanite [16], the high- $P$ phase transition induces a fraction of the trigonal-planar B atoms to increase their coordination to tetrahedral, with a new bond with a $\mathrm{H}_{2} \mathrm{O}$-oxygen. However, unlike $\mathrm{Ca}$ in colemanite and $\mathrm{Na}$ in kernite [21], no rearrangement of the Mg-coordination has been observed in kurnakovite in response to the $P$-induced phase transition.

The structural evolution of borates at high pressure may open a new window to understand the $P$ induced trigonal-planar-to-tetrahedral transition of $\mathrm{C}$ coordination reported to occur at much higher pressures (e.g. [49]), which is of large relevance in Earth science and in materials science.

\section{Acknowledgments}

Three anonymous reviewers are gratefully thanked for the fruitful and competent suggestions, which helped to increase the manuscript quality. Alessandro Guastoni (University of Padova) is thanked for the provision of the kurnakovite sample. Maurizio Polentarutti and Giorgio Bais are thanked for the support at the XRD1 beamline. Elettra Sincrotrone Trieste and DESY-Petra-III at Hamburg are acknowledged for the allocation of beamtime. Parts of this research were carried out at P02.2 at DESY, a member of the Helmholtz Association (HGF). The research leading to this result has been supported by the project CALIPSOplus under the Grant Agreement 730872 from the EU Framework Programme for Research and Innovation HORIZON 2020. FP, PL, TB, DC, FCA, GDG, SM and MM acknowledge the support from the Italian Ministry of Education (MIUR) through the projects: “Dipartimenti di Eccellenza 2018-2022", "PRIN2017 - Mineral reactivity, a key to understand large- 
scale processes" (2017L83S77), and University of Milano "La Statale" through the project "Piano di sostegno alla ricerca 2018 ".

\section{References}

[1] D. Bernhardt, I.I. Reilly, Mineral Commodity Summaries 2019, US Geological Survey, Reston, USA, 2019.

[2] M.A. Glinicki, A. Antolik, M. Gawlicki, Evaluation of compatibility of neutron-shielding boron aggregates with Portland cement in mortar, Constr. Build. Mater. 164 (2018) 731-738.

[3] M.K.A. Roslan, M. Ismail, A.B.H. Kueh, M.R.M Zin, High-density concrete: Exploring Ferro boron effects in neutron and gamma radiation shielding, Constr. Build. Mater. 215 (2019) 718-725.

[4] M.R. Palmer, G.H. Swihart, Boron isotope geochemistry: an overview, in: E.S. Grew and L.M. Anovitz (Eds.), Boron Mineralogy, Petrology and Geochemistry, Rev. Mineral., 33, 1996, pp. 709744.

[5] R.S. Carter, H. Palevsky, V.W. Myers, D.J. Hughes, Thermal neutron absorption cross sections of boron and gold, Phys. Rev. 92 (1953) 716.

[6] D.D. Di Julio, C.P. Cooper-Jensen, H. Perrey, K. Fissum, E. Rofors, J. Scherzinger, P.M. Bentley, A polyethylene- $\mathrm{B}_{4} \mathrm{C}$ based concrete for enhanced neutron shielding at neutron research facilities, Nucl. Instrum. Methods Phys. Res., Sect. A 859 (2017) 41-46.

[7] K. Okuno, M. Kawai, H. Yamada, Development of novel neutron shielding concrete. Nucl. Technol. 168 (2009) 545-552.

[8] E. Derun, A. Kipcak, Characterization of some boron minerals against neutron shielding and 12 year performance of neutron permeability, J. Radioanal. Nucl. Chem. 292 (2012) 871-878.

[9] S.B. Carpenter, R.B. Keistler, Boron and Borates, in: J.E. Kogel, N.C. Trivedi, J.M. Barker, S.T. Krukowski, (Eds.) Industrial minerals \& rocks: commodities, markets, and uses, 2006, pp. 275-283.

[10] O. Baysal, New hydrous magnesium-borate minerals in Turkey: kurnakovite, inderite, inderborite, Maden Tetkik ve Arama Dergisi, 80 (1973) 1-12.

[11] I. Koçak, Ş. Koç, Geochemical characteristics of Kırka (Sarıkaya) borate deposit, northwestern Anatolia, Turkey, J. Earth Syst. Sci. 125 (2016) 147-164.

[12] X. Li, S. Gao, Z. Liu, S. Xia, Kurnakovite deposits on the Qinghai-Tibet Plateau (II): an investigation from chemical kinetics of chloropinnoite dissolution, Environ. Earth Sci. 70, (2013) 1151-1158.

[13] Z.H. Liu, S.P. Xia, S.Y. Gao, Studies on the Kinetics of Dissolution and Transformation of $\left[2 \mathrm{MgO} \cdot 2 \mathrm{~B}_{2} \mathrm{O}_{3} \cdot \mathrm{MgCl}_{2} \cdot 14 \mathrm{H}_{2} \mathrm{O}\right]$ in water at $60^{\circ} \mathrm{C}$, Chem. Res. Chin. Univ. 20 (1999) 186-189.

[14] J. Zuo, Z.H. Liu, Phase Equilibria of the $2 \mathrm{MgO} \cdot 2 \mathrm{~B}_{2} \mathrm{O}_{3} \cdot \mathrm{MgCl}_{2} \cdot 14 \mathrm{H}_{2} \mathrm{O}+3.0 \% \mathrm{H}_{3} \mathrm{BO}_{3}+\mathrm{H}_{2} \mathrm{O}$ System at Various Temperatures, J. Chem. Eng. 55, (2010) 5280-5282.

[15] G.D. Gatta, P. Lotti, M. Merlini, H.P. Liermann, M. Fisch, High-Pressure Behavior and Phase Stability of $\mathrm{Al}_{5} \mathrm{BO}_{9}$, a Mullite-Type Ceramic Material, J. Am. Cer. Soc. 96 (2013) 2583-2592.

[16] P. Lotti, G.D. Gatta, D. Comboni, G. Guastella, M. Merlini, A. Guastoni, H.P. Liermann, Highpressure behavior and $\mathrm{P}$-induced phase transition of $\mathrm{CaB}_{3} \mathrm{O}_{4}(\mathrm{OH})_{3} \cdot \mathrm{H}_{2} \mathrm{O}$ (colemanite), J. Am. Cer. Soc. 100 (2017) 2209-2220. 
[17] P. Lotti, G.D. Gatta, N. Demitri, G. Guastella, S. Rizzato, M.A. Ortenzi, F. Magrini, D. Comboni, A. Guastoni, M.T. Fernandez-Diaz, Crystal chemistry and temperature behavior of the natural hydrous borate colemanite, a mineral commodity of boron, Phys. Chem. Miner. 45 (2018) 405-422.

[18] P. Lotti, D. Comboni, L. Gigli, L. Carlucci, E. Mossini, E. Macerata, M. Mariani, G.D. Gatta, Thermal stability and high-temperature behavior of the natural borate colemanite: An aggregate in radiation-shielding concretes, Constr. Build. Mater. 203 (2019) 679-686.

[19] G.D. Gatta, A. Guastoni, P. Lotti, G. Guastella, O. Fabelo, M.T. Fernandez-Diaz, A multimethodological study of kurnakovite: A potential B-rich aggregate, Am. Mineral. 104 (2019) 13151322.

[20] G.D. Gatta, A. Guastoni, P. Lotti, G. Guastella, O. Fabelo, M.T. Fernandez-Diaz, A multimethodological study of kernite, a mineral commodity of boron, Am. Mineral., in press, (2020) DOI: http://dx.doi.org/10.2138/am-2020-7433.

[21] D. Comboni, F. Pagliaro, G.D. Gatta, P. Lotti, S. Milani, M. Merlini, T. Battiston, K. Glazyrin, H.P. Liermann, High-pressure behaviour and phase stability of $\mathrm{Na}_{2} \mathrm{~B}_{4} \mathrm{O}_{6}(\mathrm{OH})_{2} \cdot 3 \mathrm{H}_{2} \mathrm{O}$ (kernite). J. Am. Cer. Soc. in press, (2020) DOI: 10.1111/jace.17185.

[22] C. Helvaci, M.R. Palmer, Origin and distribution of evaporite borates: the primary economic sources of boron. Elements 13 (2017) 249-254.

[23] M.N. Godlevsky, Kurnakovite, a new borate, in: Comptes Rendus (Doklady) de l'Academie des Sciences de l'URSS, Vol. 28, 1940, pp. 638-640.

[24] W.T. Schaller, M.E. Mrose, The naming of the hydrous magnesium borate minerals from Boron, California - a preliminary note, Am. Mineral. 45 (1960) 732-734.

[25] E. Corazza, Inderite: crystal structure refinement and relationship with kurnakovite, Acta Crystallogr. B32 (1976) 1329-1333.

[26] B. Zhou, V.K. Michaelis, Y. Pan, Y. Yao, K.T. Tait, B.C. Hyde, S. Kroeker, Crystal structure refinements of borate dimorphs inderite and kurnakovite using ${ }^{11} \mathrm{~B}$ and ${ }^{25} \mathrm{Mg}$ nuclear magnetic resonance and DFT calculations, Am. Mineral. 97 (2012) 1858-1865.

[27] H.E. Petch, K.S. Pennington, J.D. Cuthbert, On Christ's postulated boron-oxygen polyions in some hydrated borates of unknown crystal structures, Am. Mineral. 47 (1962) 401-404.

[28] Z.P. Razmanova, I.M. Rumanova, N.V. Belov, Crystalline structure of kurnakovite $\mathrm{Mg}_{2} \mathrm{~B}_{6} \mathrm{O}_{11} \cdot 15 \mathrm{H}_{2} \mathrm{O}=2 \mathrm{Mg}\left[\mathrm{B}_{3} \mathrm{O}_{3}(\mathrm{OH})_{5}\right] \cdot 5 \mathrm{H}_{2} \mathrm{O}$, in: Russian Academy of Sciences, Doklady Akademii Nauk, Vol. 189, No. 5, 1969, pp. 1003-1006.

[29] E. Corazza, The crystal structure of kurnakovite: a refinement, Acta Crystallogr. B30 (1974) 2194-2199.

[30] L.F. Noble, Borate Deposits in the Kramer District, Kern County, California, USGS Bulletin 785C (1926) 45-61.

[31] J.W. Siefke, The Boron open pit mine at the Kramer borate deposit. The Diversity of Mineral and Energy Resources of Southern California, Soc. Econ. Geol. Guidebook Ser. 12 (1991) 4-15.

[32] L. Obert, A.E. Long, Underground Borate Mining, Kern County, Calif, United States Department of the Interior, Bureau of Mines, 1962.

[33] Rigaku Oxford Diffraction, CrysAlisPro Software system, version 1.171.40.67a, Rigaku Corporation, Wroclaw, Poland, 2019. 
[34] H.K. Mao, J.A. Xu, P.M. Bell, Calibration of the ruby pressure gauge to 800 kbar under quasihydrostatic conditions, J. Geophys. Res. 91 (1986) 4673-4676.

[35] J.C. Chervin, B. Canny, M. Mancinelli, Ruby-spheres as pressure gauge for optically transparent

[36] Y. Fei, A. Ricolleau, M. Frank, K. Mibe, G. Shen, V. Prakapenka, Toward an internally consistent pressure scale, Proc. Natl. Acad. Sci. 104 (2007) 9182-9186.

[37] A. Rothkirch, G.D. Gatta, M. Meyer, S. Merkel, M. Merlini, H.P. Liermann, Single-crystal diffraction at the Extreme Conditions beamline P02.2: procedure for collecting and analyzing highpressure single-crystal data, J. Synchrotron Radiat. 20 (2013) 711-720.

[38] V. Petříček, M. Dušek, L. Palatinus, Crystallographic computing system JANA2006: general features, Z. Kristallogr. 229 (2014) 345-352.

[39] E.N. Maslen, A.G. Fox, M.A. O'Keefe, X-ray scattering, in: E. Prince (Ed.) International Tables for Crystallography Volume C: Mathematical, physical and chemical tables, Kluwer Academics, Dordrecht, 2006, pp. 554-590.

[40] A. R. Pawley, S. A. T. Redfern, T. J. B. Holland, Volume behavior of hydrous minerals at high pressure and temperature: I. Thermal expansion of lawsonite, zoisite, clinozoisite, and diaspore, Am. Mineral. 81 (1996) 335-340.

[41] T.J.B. Holland, R. Powell, An internally consistent thermodynamic data set for phases of petrological interest, J. Metamorph. Geol. 16 (1998) 309-343.

[42] R.J. Angel, J., Gonzalez-Platas, M. Alvaro, EosFit7c and a Fortran module (library) for equation of state calculations, Z. Kristallogr. 229 (2014) 405-419.

[43] J. Gonzalez-Platas, M. Alvaro, F. Nestola, R. Angel, EosFit7-GUI: a new graphical user interface for equation of state calculations, analyses and teaching, J. Appl. Crystallogr. 49 (2016) 1377-1382.

[44] Angel, R. J. (2011) Win_Strain. A program to calculate strain tensors from unit-cell parameters. http://www.rossangel.com/home.htm

[45] F. Birch, Finite elastic strain of cubic crystals, Phys. Rev. 71, (1947) 809-824.

[46] R.J. Angel, Equations of state, in: R.M. Hazen, R.T. Downs (Eds.), High-Temperature and HighPressure Crystal Chemistry, Rev. Mineral. Geochem. 41, 2000, pp. 35-60.

[47] R.M. Hazen, L.W. Finger, Comparative crystal chemistry, Am. Sci. 72, (1984) 143-150

[48] L. Palatinus, G. Chapuis, SUPERFLIP - a computer program for the solution of crystal structures by charge flipping in arbitrary dimensions, J. Appl. Crystallogr. 41 (2007) 786-790

[49] M. Merlini, S. Milani, J. Maurice, Structures and Crystal Chemistry of Carbonate at Earth's Mantle Conditions, in: C.E. Manning, J.F. Lin, W.L. Mao (Eds.), Carbon in Earth's Interior, Geophysical Monograph 249, 2020, pp. 87-95.

[50] K. Momma, F. Izumi, VESTA 3 for three-dimensional visualization of crystal, volumetric and morphology data, J. Appl. Crystallogr. 44 (2011) 1272-1276. 


\section{$478 \quad$ Figures captions}

Figure 1: (a) the $\mathrm{Mg}\left(\mathrm{H}_{2} \mathrm{O}\right)_{4} \mathrm{~B}_{3} \mathrm{O}_{3}(\mathrm{OH})_{5}$ unit; (b,c,d) three different views of the crystal structure of kurnakovite (displacement ellipsoid probability factor: $50 \%$ ).

Figure 2: (a) the H-bonding network of kurnakovite; (b) a view of the crystal structure of kurnakovite showing the B1-Mg1-B1 and O12-O12-O12 angles.

Figure 3: (a) $T$-induced evolution of the unit-cell parameters of kurnakovite, normalized to their ambient- $T$ values; (b) unit-cell volume vs. $T$ evolution and the refined Holland-Powell equation of state (see section 3.1 for further details).

Figure 4: (a) $P$-induced evolution of the unit-cell volumes of kurnakovite and kurnakovite-II (normalized to kurnakovite, i.e. equal to $V_{\text {kur-II }} / 3$ ) and the refined BM3-EoS pertaining to kurnakovite (see section 3.2 for further details); (b): $P$-induced evolution of the unit-cell parameters of kurnakovite, normalized to their ambient- $P$ values; (c) Variation with pressure of the $\mathrm{B} 1-\mathrm{Mg} 1-\mathrm{B} 1$ and O12-O12-O12 angles, normalized to their values at ambient- $P$; (d) Evolution of the Mg1-O1, Mg1$\mathrm{O} 5$ and Mg1-O6 bond distances (normalized to their ambient- $P$ values) with pressure.

Figure 5: Comparison between the chain configuration in kurnakovite (a) and kurnakovite-II (b). The phase transition induces one third of the B3 atomic sites in trigonal-planar coordination (shown in purple) to gain a tetrahedral coordination in kurnakovite-II (i.e., B33 shown in purple), by making a new bond with a $\mathrm{H}_{2} \mathrm{O}$-oxygen site (i.e., O43). A comparison between the unit-cell content of kurnakovite (c) and kurnakovite-II (d) is also shown. 
504 Table 1: Refined atomic fractional coordinates and isotropic displacement parameters $\left(\AA^{2}\right)$ of 505 kurnakovite at selected pressures.

\begin{tabular}{|c|c|c|c|c|c|}
\hline & $P(\mathrm{GPa})$ & $x$ & $y$ & $z$ & Uiso $\left(\AA^{2}\right)$ \\
\hline \multirow[t]{3}{*}{ Mg1 } & 0.0001 & $0.6534(6)$ & $0.2323(1)$ & $0.8021(4)$ & $0.012(3)$ \\
\hline & $4.43(5)$ & $0.6532(5)$ & $0.2352(4)$ & $0.8024(4)$ & $0.010(3)$ \\
\hline & $8.08(5)$ & $0.6525(5)$ & $0.2371(1)$ & $0.8014(4)$ & $0.009(2)$ \\
\hline \multirow[t]{3}{*}{ B1 } & 0.0001 & $0.770(2)$ & $0.2281(4)$ & $0.351(1)$ & $0.011(7)$ \\
\hline & $4.43(5)$ & $0.765(2)$ & $0.2300(4)$ & $0.348(1)$ & $0.008(5)$ \\
\hline & $8.08(5)$ & $0.762(2)$ & $0.2313(4)$ & $0.344(1)$ & $0.008(5)$ \\
\hline \multirow[t]{3}{*}{ B2 } & 0.0001 & $0.109(2)$ & $0.3528(4)$ & $0.501(1)$ & $0.011(6)$ \\
\hline & $4.43(5)$ & $0.114(2)$ & $0.3540(4)$ & $0.506(1)$ & $0.010(5)$ \\
\hline & $8.08(5)$ & $0.115(2)$ & $0.3535(4)$ & $0.510(1)$ & $0.009(5)$ \\
\hline \multirow[t]{3}{*}{ B3 } & 0.0001 & $0.985(2)$ & $0.1066(4)$ & $0.314(1)$ & $0.012(7)$ \\
\hline & $4.43(5)$ & $0.984(2)$ & $0.0977(4)$ & $0.311(1)$ & $0.011(6)$ \\
\hline & $8.08(5)$ & $0.977(2)$ & $0.0928(4)$ & $0.306(1)$ & $0.009(5)$ \\
\hline \multirow[t]{3}{*}{ O1 } & 0.0001 & $0.922(1)$ & $0.3219(3)$ & $0.920(1)$ & $0.029(8)$ \\
\hline & $4.43(5)$ & $0.926(2)$ & $0.3205(3)$ & $0.926(1)$ & $0.023(6)$ \\
\hline & $8.08(5)$ & $0.925(1)$ & $0.3228(3)$ & $0.9294(9)$ & $0.020(5)$ \\
\hline \multirow[t]{3}{*}{$\mathrm{O} 2$} & 0.0001 & $0.593(1)$ & $0.4095(3)$ & $0.7767(9)$ & $0.020(6)$ \\
\hline & $4.43(5)$ & $0.586(1)$ & $0.4158(3)$ & $0.7702(9)$ & $0.017(5)$ \\
\hline & $8.08(5)$ & $0.579(1)$ & $0.4181(3)$ & $0.7636(8)$ & $0.017(5)$ \\
\hline \multirow[t]{3}{*}{$\mathrm{O} 3$} & 0.0001 & $0.385(3)$ & $0.1355(3)$ & $0.669(1)$ & $0.022(6)$ \\
\hline & $4.43(5)$ & $0.383(1)$ & $0.1356(3)$ & $0.6783(9)$ & $0.017(6)$ \\
\hline & $8.08(5)$ & $0.387(1)$ & $0.1358(3)$ & $0.6858(9)$ & $0.016(5)$ \\
\hline \multirow[t]{3}{*}{$\mathrm{O} 4$} & 0.0001 & $0.670(1)$ & $0.0349(3)$ & $0.808(1)$ & $0.017(5)$ \\
\hline & $4.43(5)$ & $0.665(1)$ & $0.0274(3)$ & $0.7984(9)$ & $0.014(5)$ \\
\hline & $8.08(5)$ & $0.667(1)$ & $0.0254(3)$ & $0.7932(8)$ & $0.013(4)$ \\
\hline \multirow[t]{3}{*}{ O5 } & 0.0001 & $0.650(1)$ & $0.1916(3)$ & $0.4734(9)$ & $0.015(5)$ \\
\hline & $4.43(5)$ & $0.646(1)$ & $0.1921(3)$ & $0.4717(8)$ & $0.012(4)$ \\
\hline & $8.08(5)$ & $0.642(1)$ & $0.1923(3)$ & $0.4698(8)$ & $0.011(4)$ \\
\hline \multirow[t]{3}{*}{ O6 } & 0.0001 & $0.671(1)$ & $0.2635(3)$ & $0.1436(8)$ & $0.017(6)$ \\
\hline & $4.43(5)$ & $0.667(1)$ & $0.2738(3)$ & $0.1421(8)$ & $0.012(4)$ \\
\hline & $8.08(5)$ & $0.662(1)$ & $0.2788(3)$ & $0.1407(8)$ & $0.012(4)$ \\
\hline \multirow[t]{3}{*}{$\mathrm{O} 7$} & 0.0001 & $0.812(1)$ & $0.1030(3)$ & $0.2692(9)$ & $0.013(5)$ \\
\hline & $4.43(5)$ & $0.804(1)$ & $0.0990(3)$ & $0.2547(9)$ & $0.012(4)$ \\
\hline & $8.08(5)$ & $0.804(1)$ & $0.0990(3)$ & $0.2489(8)$ & $0.010(4)$ \\
\hline \multirow[t]{3}{*}{ O8 } & 0.0001 & $0.932(1)$ & $0.3339(3)$ & $0.5043(8)$ & $0.012(5)$ \\
\hline & $4.43(5)$ & $0.935(1)$ & $0.3376(3)$ & $0.5088(8)$ & $0.011(4)$ \\
\hline & $8.08(5)$ & $0.930(1)$ & $0.3391(3)$ & $0.5035(8)$ & $0.011(4)$ \\
\hline
\end{tabular}




\begin{tabular}{llllll}
\hline & & & & & \\
O9 & 0.0001 & $0.152(1)$ & $0.4407(3)$ & $0.3558(8)$ & $0.014(5)$ \\
& $4.43(5)$ & $0.156(1)$ & $0.4428(3)$ & $0.3566(8)$ & $0.011(4)$ \\
& $8.08(5)$ & $0.165(1)$ & $0.4444(3)$ & $0.3616(7)$ & $0.010(4)$ \\
O10 & 0.0001 & $0.252(1)$ & $0.4094(3)$ & $0.736(1)$ & $0.025(7)$ \\
& $4.43(5)$ & $0.249(1)$ & $0.4135(4)$ & $0.7440(7)$ & $0.021(5)$ \\
& $8.08(5)$ & $0.248(1)$ & $0.4130(3)$ & $0.7558(9)$ & $0.016(5)$ \\
O11 & 0.0001 & $0.129(1)$ & $0.2209(3)$ & $0.4126(9)$ & $0.016(5)$ \\
& $4.43(5)$ & $0.131(1)$ & $0.2150(3)$ & $0.416(1)$ & $0.013(5)$ \\
& $8.08(5)$ & $0.131(1)$ & $0.2115(3)$ & $0.4169(8)$ & $0.012(4)$ \\
O12 & 0.0001 & $0.018(1)$ & $0.9876(3)$ & $0.2495(9)$ & $0.020(6)$ \\
& $4.43(5)$ & $0.014(1)$ & $0.9721(3)$ & $0.2480(7)$ & $0.018(5)$ \\
& $8.08(5)$ & $0.019(1)$ & $0.9624(3)$ & $0.2477(9)$ & $0.016(5)$ \\
O13 & 0.0001 & $0.291(1)$ & $0.2447(3)$ & $0.056(1)$ & $0.027(7)$ \\
& $4.43(5)$ & $0.293(1)$ & $0.2492(3)$ & $0.0631(9)$ & $0.018(5)$ \\
& $8.08(5)$ & $0.295(1)$ & $0.2497(3)$ & $0.0701(9)$ & $0.015(4)$ \\
\hline
\end{tabular}


535 Table 2: Refined atomic fractional coordinates and isotropic displacement parameters $\left(\AA^{2}\right)$ of 536 kurnakovite-II at 11.11(5) GPa.

\begin{tabular}{|c|c|c|c|c|}
\hline & $x$ & $y$ & $z$ & $\operatorname{Uiso}\left(\AA^{2}\right)$ \\
\hline Mg11 & $0.742(5)$ & $0.0257(4)$ & $0.8858(5)$ & $0.013(4)$ \\
\hline Mg12 & $0.907(5)$ & $0.6519(4)$ & $0.4281(6)$ & $0.014(4)$ \\
\hline Mg13 & $0.452(5)$ & $0.6909(4)$ & $0.2551(5)$ & $0.014(4)$ \\
\hline B11 & $0.633(2)$ & $0.913(1)$ & $0.116(2)$ & $0.01(1)$ \\
\hline B12 & $0.010(2)$ & $0.744(1)$ & $0.197(2)$ & $0.011(9)$ \\
\hline B13 & $0.694(2)$ & $0.441(1)$ & $0.552(2)$ & $0.01(1)$ \\
\hline B21 & $0.861(2)$ & $0.009(1)$ & $0.253(2)$ & $0.01(1)$ \\
\hline B22 & $0.806(2)$ & $0.665(1)$ & $0.042(2)$ & $0.01(1)$ \\
\hline B23 & $0.483(2)$ & $0.322(1)$ & $0.403(2)$ & $0.01(1)$ \\
\hline B31 & $0.737(2)$ & $0.156(1)$ & $0.234(2)$ & $0.01(1)$ \\
\hline B32 & $0.907(2)$ & $0.507(1)$ & $0.082(2)$ & $0.01(1)$ \\
\hline B33 & $0.606(2)$ & $0.188(1)$ & $0.506(2)$ & $0.01(1)$ \\
\hline O11 & $0.895(1)$ & $0.0849(9)$ & $0.007(1)$ & $0.023(8)$ \\
\hline $\mathrm{O} 12$ & $0.748(1)$ & $0.5464(8)$ & $0.297(1)$ & $0.019(7)$ \\
\hline $\mathrm{O} 13$ & $0.632(1)$ & $0.7420(8)$ & $0.329(1)$ & $0.021(8)$ \\
\hline $\mathrm{O} 21$ & $0.776(1)$ & $0.8876(8)$ & $0.765(1)$ & $0.019(8)$ \\
\hline $\mathrm{O} 22$ & $0.886(1)$ & $0.8063(8)$ & $0.538(1)$ & $0.019(8)$ \\
\hline $\mathrm{O} 23$ & $0.448(1)$ & $0.5432(8)$ & $0.113(1)$ & $0.017(7)$ \\
\hline O31 & $0.415(1)$ & $0.0074(8)$ & $0.244(1)$ & $0.015(7)$ \\
\hline $\mathrm{O} 32$ & $0.086(1)$ & $0.7224(9)$ & $0.512(1)$ & $0.022(9)$ \\
\hline $\mathrm{O} 33$ & $0.256(1)$ & $0.6457(8)$ & $0.191(1)$ & $0.018(8)$ \\
\hline O41 & $0.684(1)$ & $0.1695(8)$ & $0.974(1)$ & $0.019(8)$ \\
\hline $\mathrm{O} 42$ & $0.954(1)$ & $0.4862(8)$ & $0.361(1)$ & $0.018(8)$ \\
\hline $\mathrm{O} 43$ & $0.446(1)$ & $0.8500(8)$ & $0.383(1)$ & $0.016(8)$ \\
\hline O51 & $0.148(1)$ & $0.8235(8)$ & $0.194(1)$ & $0.015(7)$ \\
\hline O52 & $0.821(1)$ & $0.5527(8)$ & $0.556(1)$ & $0.014(7)$ \\
\hline O53 & $0.512(1)$ & $0.8143(7)$ & $0.141(1)$ & $0.014(7)$ \\
\hline O61 & $0.631(1)$ & $0.8887(8)$ & $0.981(1)$ & $0.018(8)$ \\
\hline O62 & $0.975(1)$ & $0.7818(8)$ & $0.315(1)$ & $0.015(7)$ \\
\hline O63 & $0.367(1)$ & $0.5396(7)$ & $0.340(1)$ & $0.013(7)$ \\
\hline O71 & $0.634(1)$ & $0.0530(8)$ & $0.160(1)$ & $0.014(7)$ \\
\hline $\mathrm{O} 72$ & $0.985(1)$ & $0.5967(8)$ & $0.173(1)$ & $0.013(7)$ \\
\hline $\mathrm{O} 73$ & $0.288(1)$ & $0.6844(7)$ & $0.459(1)$ & $0.014(7)$ \\
\hline O81 & $0.743(1)$ & $0.9026(8)$ & $0.178(1)$ & $0.019(9)$ \\
\hline O82 & $0.932(1)$ & $0.7675(8)$ & $0.101(1)$ & $0.014(7)$ \\
\hline O83 & $0.606(1)$ & $0.4361(8)$ & $0.447(1)$ & $0.013(7)$ \\
\hline O91 & $0.977(1)$ & $0.0213(8)$ & $0.192(1)$ & $0.015(7)$ \\
\hline O92 & $0.702(1)$ & $0.6473(7)$ & $0.117(1)$ & $0.013(8)$ \\
\hline O93 & $0.628(1)$ & $0.6784(8)$ & $0.535(1)$ & $0.015(7)$ \\
\hline O101 & $0.889(1)$ & $0.9778(8)$ & $0.370(1)$ & $0.020(9)$ \\
\hline O102 & $0.767(1)$ & $0.6999(8)$ & $0.929(1)$ & $0.018(8)$ \\
\hline O103 & $0.439(1)$ & $0.3196(9)$ & $0.279(1)$ & $0.021(9)$ \\
\hline O111 & $0.849(1)$ & $0.1404(8)$ & $0.267(1)$ & $0.016(8)$ \\
\hline $\mathrm{O} 112$ & $0.817(1)$ & $0.5308(8)$ & $0.007(1)$ & $0.017(8)$ \\
\hline $\mathrm{O} 113$ & $0.500(1)$ & $0.8037(8)$ & $0.580(1)$ & $0.016(8)$ \\
\hline O121 & $0.728(1)$ & $0.2790(8)$ & $0.259(1)$ & $0.029(8)$ \\
\hline O122 & $0.904(1)$ & $0.3778(8)$ & $0.056(1)$ & $0.029(8)$ \\
\hline O123 & $0.642(1)$ & $0.0844(7)$ & $0.436(1)$ & $0.016(8)$ \\
\hline O131 & $0.580(1)$ & $0.3476(8)$ & $0.099(1)$ & $0.029(9)$ \\
\hline
\end{tabular}




\begin{tabular}{lllll}
\hline O132 & $0.207(1)$ & $0.9829(9)$ & $0.428(1)$ & $0.022(8)$ \\
O133 & $0.073(1)$ & $0.3360(8)$ & $0.215(1)$ & $0.019(8)$ \\
\hline
\end{tabular}


Table 3: Refined atomic fractional coordinates and equivalent displacement parameters $\left(\AA^{2}\right)$ of 542 kurnakovite at selected temperatures.

\begin{tabular}{|c|c|c|c|c|c|}
\hline & $T(\mathrm{~K})$ & $x$ & $y$ & $z$ & Ueq \\
\hline \multirow[t]{3}{*}{$\mathrm{Mg} 1$} & 100 & $0.65344(5)$ & $0.23143(4)$ & $0.80301(6)$ & $0.0059(2)$ \\
\hline & 297 & $0.65288(7)$ & $0.23211(6)$ & $0.8013(1)$ & $0.0140(3)$ \\
\hline & 373 & $0.65279(9)$ & $0.23232(8)$ & $0.8009(1)$ & $0.0222(3)$ \\
\hline \multirow[t]{3}{*}{ B1 } & 100 & $0.7685(2)$ & $0.2262(1)$ & $0.3512(2)$ & $0.0060(4)$ \\
\hline & 297 & $0.7697(2)$ & $0.2271(2)$ & $0.3505(3)$ & $0.0130(6)$ \\
\hline & 373 & $0.7706(3)$ & $0.2276(2)$ & $0.3513(4)$ & $0.0207(8)$ \\
\hline \multirow[t]{3}{*}{ B2 } & 100 & $0.1127(2)$ & $0.3529(1)$ & $0.5026(2)$ & $0.0062(4)$ \\
\hline & 297 & $0.1108(2)$ & $0.3527(2)$ & $0.5011(3)$ & $0.0139(6)$ \\
\hline & 373 & $0.1116(3)$ & $0.3534(2)$ & $0.5013(4)$ & $0.0204(8)$ \\
\hline \multirow[t]{3}{*}{ B3 } & 100 & $0.9823(2)$ & $0.1048(1)$ & $0.3098(2)$ & $0.0063(4)$ \\
\hline & 297 & $0.9820(2)$ & $0.1054(2)$ & $0.3112(3)$ & $0.0142(6)$ \\
\hline & 373 & $0.9824(3)$ & $0.1062(2)$ & $0.3123(4)$ & $0.0217(8)$ \\
\hline \multirow[t]{3}{*}{ O1 } & 100 & $0.9236(1)$ & $0.3210(1)$ & $0.9222(2)$ & $0.0109(3)$ \\
\hline & 297 & $0.9208(2)$ & $0.3214(1)$ & $0.9190(3)$ & $0.0263(6)$ \\
\hline & 373 & $0.9199(3)$ & $0.3214(2)$ & $0.9183(3)$ & $0.0384(8)$ \\
\hline \multirow[t]{3}{*}{$\mathrm{O} 2$} & 100 & $0.5971(1)$ & $0.40949(9)$ & $0.7826(2)$ & $0.0096(3)$ \\
\hline & 297 & $0.5943(2)$ & $0.4091(1)$ & $0.7769(3)$ & $0.0242(6)$ \\
\hline & 373 & $0.5938(3)$ & $0.4091(2)$ & $0.7740(4)$ & $0.0347(8)$ \\
\hline \multirow[t]{3}{*}{$\mathrm{O} 3$} & 100 & $0.3829(1)$ & $0.13431(9)$ & $0.6667(2)$ & $0.0085(3)$ \\
\hline & 297 & $0.3833(2)$ & $0.1348(1)$ & $0.6686(2)$ & $0.0207(5)$ \\
\hline & 373 & $0.3849(2)$ & $0.1353(2)$ & $0.6696(3)$ & $0.0301(7)$ \\
\hline \multirow[t]{3}{*}{$\mathrm{O} 4$} & 100 & $0.6691(1)$ & $0.03425(8)$ & $0.8070(2)$ & $0.0079(3)$ \\
\hline & 297 & $0.6688(2)$ & $0.0349(1)$ & $0.8073(2)$ & $0.0179(5)$ \\
\hline & 373 & $0.6701(2)$ & $0.0357(2)$ & $0.8076(3)$ & $0.0271(7)$ \\
\hline \multirow[t]{3}{*}{ O5 } & 100 & $0.6501(1)$ & $0.19150(9)$ & $0.4753(1)$ & $0.0068(3)$ \\
\hline & 297 & $0.6513(2)$ & $0.1924(1)$ & $0.4737(2)$ & $0.0162(5)$ \\
\hline & 373 & $0.6521(2)$ & $0.1931(2)$ & $0.4737(3)$ & $0.0244(6)$ \\
\hline \multirow[t]{3}{*}{ O6 } & 100 & $0.6687(1)$ & $0.26157(9)$ & $0.1415(1)$ & $0.0076(3)$ \\
\hline & 297 & $0.6713(2)$ & $0.2634(1)$ & $0.1416(2)$ & $0.0191(5)$ \\
\hline & 373 & $0.6727(3)$ & $0.2645(2)$ & $0.1427(3)$ & $0.0280(7)$ \\
\hline \multirow[t]{3}{*}{$\mathrm{O} 7$} & 100 & $0.8094(1)$ & $0.10167(8)$ & $0.2680(1)$ & $0.0064(3)$ \\
\hline & 297 & $0.8102(2)$ & $0.1031(1)$ & $0.2675(2)$ & $0.0149(5)$ \\
\hline & 373 & $0.8101(2)$ & $0.1032(2)$ & $0.2676(3)$ & $0.0235(6)$ \\
\hline \multirow[t]{3}{*}{ O8 } & 100 & $0.9338(1)$ & $0.33384(8)$ & $0.5063(1)$ & $0.0065(3)$ \\
\hline & 297 & $0.9328(2)$ & $0.3340(1)$ & $0.5056(2)$ & $0.0154(5)$ \\
\hline & 373 & $0.9321(2)$ & $0.3332(2)$ & $0.5049(3)$ & $0.0236(6)$ \\
\hline
\end{tabular}




\begin{tabular}{|c|c|c|c|c|c|}
\hline \multirow[t]{3}{*}{ O9 } & 100 & $0.1531(1)$ & $0.44317(9)$ & $0.3590(1)$ & $0.0076(3)$ \\
\hline & 297 & $0.1492(2)$ & $0.4400(1)$ & $0.3542(2)$ & $0.0179(5)$ \\
\hline & 373 & $0.1484(2)$ & $0.4390(2)$ & $0.3530(3)$ & $0.0274(7)$ \\
\hline \multirow[t]{3}{*}{$\mathrm{O} 10$} & 100 & $0.2527(1)$ & $0.40606(9)$ & $0.7394(2)$ & $0.0088(3)$ \\
\hline & 297 & $0.2505(2)$ & $0.4096(2)$ & $0.7349(2)$ & $0.0247(5)$ \\
\hline & 373 & $0.2484(3)$ & $0.4096(2)$ & $0.7330(3)$ & $0.0358(8)$ \\
\hline \multirow[t]{3}{*}{ O11 } & 100 & $0.1298(1)$ & $0.22198(8)$ & $0.4099(1)$ & $0.0068(3)$ \\
\hline & 297 & $0.1285(2)$ & $0.2214(1)$ & $0.4137(2)$ & $0.0166(5)$ \\
\hline & 373 & $0.1289(2)$ & $0.2214(2)$ & $0.4154(3)$ & $0.0256(6)$ \\
\hline \multirow[t]{3}{*}{$\mathrm{O} 12$} & 100 & $0.0156(1)$ & $0.98708(9)$ & $0.2466(2)$ & $0.0088(3)$ \\
\hline & 297 & $0.0156(2)$ & $0.9881(1)$ & $0.2489(2)$ & $0.0215(5)$ \\
\hline & 373 & $0.0162(2)$ & $0.9892(2)$ & $0.2498(3)$ & $0.0312(7)$ \\
\hline \multirow[t]{3}{*}{$\mathrm{O} 13$} & 100 & $0.2877(1)$ & $0.2421(1)$ & $0.0505(2)$ & $0.0115(3)$ \\
\hline & 297 & $0.2861(2)$ & $0.2431(2)$ & $0.0519(3)$ & $0.0302(7)$ \\
\hline & 373 & $0.2866(3)$ & $0.2434(3)$ & $0.0536(5)$ & $0.044(1)$ \\
\hline \multirow[t]{3}{*}{ H1 } & 100 & $0.998(4)$ & $0.364(3)$ & $0.063(5)$ & 0.038 \\
\hline & 297 & $0.987(5)$ & $0.360(4)$ & $0.056(7)$ & 0.038 \\
\hline & 373 & $0.998(5)$ & $0.366(4)$ & $0.051(8)$ & 0.038 \\
\hline \multirow[t]{3}{*}{$\mathrm{H} 2$} & 100 & $0.967(4)$ & $0.333(3)$ & $0.817(5)$ & 0.038 \\
\hline & 297 & $0.979(4)$ & $0.335(4)$ & $0.817(6)$ & 0.038 \\
\hline & 373 & $0.960(5)$ & $0.332(4)$ & $0.828(7)$ & 0.038 \\
\hline \multirow[t]{3}{*}{$\mathrm{H} 3$} & 100 & $0.656(4)$ & $0.466(3)$ & $0.719(5)$ & 0.038 \\
\hline & 297 & $0.678(5)$ & $0.470(4)$ & $0.714(6)$ & 0.038 \\
\hline & 373 & $0.680(5)$ & $0.477(4)$ & $0.734(7)$ & 0.038 \\
\hline \multirow[t]{3}{*}{$\mathrm{H} 4$} & 100 & $0.487(4)$ & $0.414(3)$ & $0.755(4)$ & 0.038 \\
\hline & 297 & $0.477(5)$ & $0.417(4)$ & $0.756(6)$ & 0.038 \\
\hline & 373 & $0.487(6)$ & $0.406(4)$ & $0.742(7)$ & 0.038 \\
\hline \multirow[t]{3}{*}{ H5 } & 100 & $0.310(4)$ & $0.165(3)$ & $0.588(5)$ & 0.038 \\
\hline & 297 & $0.311(5)$ & $0.167(4)$ & $0.585(6)$ & 0.038 \\
\hline & 373 & $0.313(5)$ & $0.161(4)$ & $0.593(7)$ & 0.038 \\
\hline \multirow[t]{3}{*}{ H6 } & 100 & $0.328(4)$ & $0.062(3)$ & $0.683(5)$ & 0.038 \\
\hline & 297 & $0.321(4)$ & $0.059(4)$ & $0.692(6)$ & 0.038 \\
\hline & 373 & $0.322(5)$ & $0.059(4)$ & $0.692(7)$ & 0.038 \\
\hline \multirow[t]{3}{*}{$\mathrm{H} 7$} & 100 & $0.754(4)$ & $0.024(3)$ & $0.770(5)$ & 0.038 \\
\hline & 297 & $0.756(5)$ & $0.022(4)$ & $0.768(6)$ & 0.038 \\
\hline & 373 & $0.758(5)$ & $0.031(4)$ & $0.767(7)$ & 0.038 \\
\hline \multirow[t]{2}{*}{ H8 } & 100 & $0.698(4)$ & $0.037(3)$ & $0.946(5)$ & 0.038 \\
\hline & 297 & $0.696(5)$ & $0.040(4)$ & $0.936(7)$ & 0.038 \\
\hline
\end{tabular}




\begin{tabular}{|c|c|c|c|c|c|}
\hline & 373 & $0.693(5)$ & $0.041(4)$ & $0.938(8)$ & 0.038 \\
\hline H9 & $\begin{array}{l}100 \\
297 \\
373\end{array}$ & $\begin{array}{l}0.549(4) \\
0.547(5) \\
0.570(6)\end{array}$ & $\begin{array}{l}0.127(3) \\
0.132(4) \\
0.139(4)\end{array}$ & $\begin{array}{l}0.389(5) \\
0.398(6) \\
0.387(7)\end{array}$ & $\begin{array}{l}0.038 \\
0.038 \\
0.038\end{array}$ \\
\hline $\mathrm{H} 10$ & $\begin{array}{l}100 \\
297 \\
373\end{array}$ & $\begin{array}{l}0.566(4) \\
0.576(5) \\
0.581(6)\end{array}$ & $\begin{array}{l}0.259(3) \\
0.262(4) \\
0.260(4)\end{array}$ & $\begin{array}{l}0.139(4) \\
0.146(6) \\
0.145(7)\end{array}$ & $\begin{array}{l}0.038 \\
0.038 \\
0.038\end{array}$ \\
\hline H11 & $\begin{array}{l}100 \\
297 \\
373\end{array}$ & $\begin{array}{l}0.121(3) \\
0.131(5) \\
0.125(5)\end{array}$ & $\begin{array}{l}0.511(3) \\
0.501(4) \\
0.500(4)\end{array}$ & $\begin{array}{l}0.397(5) \\
0.382(6) \\
0.395(7)\end{array}$ & $\begin{array}{l}0.038 \\
0.038 \\
0.038\end{array}$ \\
\hline $\mathrm{H} 12$ & $\begin{array}{l}100 \\
297 \\
373\end{array}$ & $\begin{array}{l}0.265(3) \\
0.240(4) \\
0.257(6)\end{array}$ & $\begin{array}{l}0.486(3) \\
0.495(4) \\
0.468(5)\end{array}$ & $\begin{array}{l}0.797(5) \\
0.801(6) \\
0.778(8)\end{array}$ & $\begin{array}{l}0.038 \\
0.038 \\
0.038\end{array}$ \\
\hline H13 & $\begin{array}{l}100 \\
297 \\
373\end{array}$ & $\begin{array}{l}0.926(4) \\
0.927(5) \\
0.932(5)\end{array}$ & $\begin{array}{l}0.921(3) \\
0.920(4) \\
0.929(5)\end{array}$ & $\begin{array}{l}0.168(5) \\
0.178(6) \\
0.174(7)\end{array}$ & $\begin{array}{l}0.038 \\
0.038 \\
0.038\end{array}$ \\
\hline H14 & $\begin{array}{l}100 \\
297 \\
373\end{array}$ & $\begin{array}{l}0.259(4) \\
0.272(4) \\
0.272(5)\end{array}$ & $\begin{array}{l}0.262(3) \\
0.258(4) \\
0.267(4)\end{array}$ & $\begin{array}{l}0.158(5) \\
0.165(7) \\
0.174(7)\end{array}$ & $\begin{array}{l}0.038 \\
0.038 \\
0.038\end{array}$ \\
\hline H15 & $\begin{array}{l}100 \\
297 \\
373\end{array}$ & $\begin{array}{l}0.273(3) \\
0.257(4) \\
0.274(5)\end{array}$ & $\begin{array}{l}0.298(3) \\
0.292(4) \\
0.295(5)\end{array}$ & $\begin{array}{l}0.967(5) \\
0.964(6) \\
0.980(7)\end{array}$ & $\begin{array}{l}0.038 \\
0.038 \\
0.038\end{array}$ \\
\hline
\end{tabular}


Table 4: Selected statistical parameters pertaining to the structure refinements of kurnakovite based on the intensity XRD data collected at varying temperatures and pressures.

566

\begin{tabular}{lccccccc}
\hline$T(\mathrm{~K})$ & $\begin{array}{c}\text { Unique } \\
\text { reflections }\end{array}$ & $\begin{array}{c}\text { Observed } \\
\text { reflections } \\
I>3 \sigma(I)\end{array}$ & $\begin{array}{c}\text { Refined } \\
\text { variables }\end{array}$ & $\begin{array}{c}R_{\text {int }} \\
\text { (Friedel- } \\
\text { all) }\end{array}$ & $\begin{array}{c}R_{1} \\
\text { (obs) }\end{array}$ & $\begin{array}{c}R_{1} \\
\text { (all) }\end{array}$ & $w R_{1}$ (obs) \\
\hline 100 & 2351 & 2273 & 197 & 2.9 & 0.0444 & 0.0451 & 0.0642 \\
120 & 2374 & 2294 & 197 & 6.6 & 0.0533 & 0.0540 & 0.0832 \\
140 & 2377 & 2307 & 197 & 6.7 & 0.0552 & 0.0559 & 0.0933 \\
160 & 2372 & 2297 & 197 & 6.2 & 0.0499 & 0.0505 & 0.0731 \\
180 & 2374 & 2300 & 197 & 6.5 & 0.0483 & 0.0489 & 0.0713 \\
200 & 2384 & 2308 & 197 & 6.2 & 0.0531 & 0.0542 & 0.0898 \\
220 & 2385 & 2308 & 197 & 6.0 & 0.0540 & 0.0548 & 0.0871 \\
240 & 2385 & 2300 & 197 & 6.5 & 0.0537 & 0.0547 & 0.0836 \\
260 & 2389 & 2298 & 197 & 6.3 & 0.0530 & 0.0540 & 0.0808 \\
280 & 2395 & 2291 & 197 & 6.6 & 0.0539 & 0.0555 & 0.0830 \\
297 & 2297 & 2287 & 197 & 6.4 & 0.0565 & 0.0566 & 0.0875 \\
353 & 2321 & 2315 & 197 & 7.4 & 0.0529 & 0.0542 & 0.1004 \\
373 & 2315 & 2302 & 197 & 7.5 & 0.0588 & 0.0606 & 0.1161 \\
\hline$P(\mathrm{GPa})$ & & & & & & & \\
0.0001 & 1573 & 945 & 69 & 3.4 & 0.0790 & 0.1289 & 0.0850 \\
$1.07(5)$ & 1523 & 1173 & 69 & 2.0 & 0.0899 & 0.1099 & 0.1022 \\
$1.83(5)$ & 1511 & 1202 & 69 & 2.2 & 0.0833 & 0.0989 & 0.1020 \\
$3.21(5)$ & 1474 & 956 & 69 & 3.1 & 0.0895 & 0.1332 & 0.0928 \\
$4.43(5)$ & 1448 & 1116 & 69 & 5.6 & 0.0861 & 0.1022 & 0.1178 \\
$5.35(5)$ & 1411 & 1001 & 69 & 2.1 & 0.0829 & 0.1066 & 0.0909 \\
$6.54(5)$ & 1391 & 919 & 69 & 3.3 & 0.0850 & 0.1112 & 0.0916 \\
$8.08(5)$ & 1381 & 1076 & 69 & 2.6 & 0.0795 & 0.0950 & 0.0967 \\
$9.23(5)$ & 1353 & 975 & 69 & 3.3 & 0.0810 & 0.1034 & 0.0956 \\
$11.11(5)$ & 2791 & 1752 & 205 & 5.5 & 0.0764 & 0.1169 & 0.0802 \\
$12.21(5)$ & 2442 & 1159 & 205 & 7.4 & 0.0962 & 0.1798 & 0.0986 \\
\hline & & & & & & & \\
\hline
\end{tabular}


Table 5: Unit-cell parameters of kurnakovite with temperature.

570

\begin{tabular}{cccccccc}
\hline$T(\mathrm{~K})$ & $V\left(\AA^{3}\right)$ & $a(\AA)$ & $b(\AA)$ & $c(\AA)$ & $\alpha\left(^{\circ}\right)$ & $\beta\left({ }^{\circ}\right)$ & $\gamma\left({ }^{\circ}\right)$ \\
\hline 100 & $495.49(5)$ & $8.3152(2)$ & $10.5959(8)$ & $6.4187(5)$ & $99.000(6)$ & $109.026(5)$ & $105.773(5)$ \\
120 & $495.81(5)$ & $8.3167(2)$ & $10.5969(7)$ & $6.4199(4)$ & $98.991(5)$ & $109.020(5)$ & $105.763(5)$ \\
140 & $496.10(5)$ & $8.3186(2)$ & $10.6001(7)$ & $6.4208(4)$ & $98.981(5)$ & $109.011(5)$ & $105.765(5)$ \\
160 & $496.59(5)$ & $8.3208(2)$ & $10.6003(7)$ & $6.4228(4)$ & $98.967(5)$ & $109.007(5)$ & $105.752(5)$ \\
180 & $497.09(5)$ & $8.3233(2)$ & $10.6000(7)$ & $6.4254(4)$ & $98.960(5)$ & $109.001(5)$ & $105.727(5)$ \\
200 & $497.55(5)$ & $8.3261(2)$ & $10.5994(7)$ & $6.4280(4)$ & $98.942(5)$ & $108.994(5)$ & $105.705(5)$ \\
220 & $498.09(5)$ & $8.3294(2)$ & $10.5990(7)$ & $6.4308(4)$ & $98.929(5)$ & $108.987(4)$ & $105.679(5)$ \\
240 & $498.65(5)$ & $8.3327(2)$ & $10.5987(7)$ & $6.4338(4)$ & $98.913(5)$ & $108.985(4)$ & $105.652(4)$ \\
260 & $499.23(5)$ & $8.3363(2)$ & $10.5988(7)$ & $6.4365(4)$ & $98.900(5)$ & $108.981(4)$ & $105.625(4)$ \\
280 & $499.86(5)$ & $8.3401(2)$ & $10.5992(7)$ & $6.4397(4)$ & $98.897(5)$ & $108.985(4)$ & $105.599(4)$ \\
297 & $500.52(5)$ & $8.3442(2)$ & $10.6002(7)$ & $6.4427(4)$ & $98.865(5)$ & $108.980(4)$ & $105.577(4)$ \\
353 & $502.37(4)$ & $8.3559(2)$ & $10.6062(6)$ & $6.4490(4)$ & $98.805(5)$ & $108.972(4)$ & $105.525(4)$ \\
373 & $503.21(4)$ & $8.3612(2)$ & $10.6109(6)$ & $6.4514(4)$ & $98.787(5)$ & $108.972(4)$ & $105.507(4)$ \\
393 & $506.7(6)$ & $8.38(5)$ & $10.631(7)$ & $6.480(5)$ & $98.67(6)$ & $109.14(7)$ & $105.62(6)$ \\
\hline
\end{tabular}


573 Table 6: Unit-cell parameters of kurnakovite and kurnakovite-II with pressure (*: data collected in 574 decompression).

575

\begin{tabular}{cccccccc}
\hline$P(\mathrm{GPa})$ & $V\left(\AA^{3}\right)$ & $a(\AA)$ & $b(\AA)$ & $c(\AA)$ & $\alpha\left(^{\circ}\right)$ & $\beta\left(^{\circ}\right)$ & $\gamma\left({ }^{\circ}\right)$ \\
\hline 0.0001 & $497.9(5)$ & $8.308(7)$ & $10.599(2)$ & $6.442(3)$ & $98.85(3)$ & $109.09(6)$ & $105.57(4)$ \\
$1.07(5)$ & $485.1(2)$ & $8.274(3)$ & $10.4270(7)$ & $6.3957(7)$ & $99.031(9)$ & $109.01(2)$ & $105.29(2)$ \\
$1.83(5)$ & $477.2(2)$ & $8.227(3)$ & $10.341(1)$ & $6.3697(9)$ & $99.11(1)$ & $109.00(2)$ & $105.16(2)$ \\
$3.21(5)$ & $463.3(2)$ & $8.168(3)$ & $10.192(1)$ & $6.320(1)$ & $99.22(1)$ & $109.01(2)$ & $104.86(2)$ \\
$4.43(5)$ & $453.4(2)$ & $8.125(3)$ & $10.0830(7)$ & $6.2764(9)$ & $99.309(9)$ & $108.95(2)$ & $104.67(1)$ \\
$5.35(5)$ & $446.6(2)$ & $8.088(3)$ & $10.0110(6)$ & $6.247(1)$ & $99.356(9)$ & $108.93(2)$ & $104.47(1)$ \\
$6.54(5)$ & $437.9(2)$ & $8.047(3)$ & $9.9193(9)$ & $6.2068(9)$ & $99.41(1)$ & $108.90(2)$ & $104.29(2)$ \\
$8.08(5)$ & $431.5(2)$ & $8.023(3)$ & $9.8404(8)$ & $6.1725(9)$ & $99.46(1)$ & $108.78(2)$ & $104.10(1)$ \\
$9.23(5)$ & $424.0(2)$ & $7.978(3)$ & $9.7603(8)$ & $6.141(1)$ & $99.49(1)$ & $108.80(2)$ & $103.87(2)$ \\
$11.11(5)$ & $1212.8(3)$ & $11.011(2)$ & $10.827(2)$ & $11.286(2)$ & $99.65(1)$ & $93.96(2)$ & $112.45(2)$ \\
$12.21(5)$ & $1199.5(8)$ & $10.967(4)$ & $10.788(4)$ & $11.237(4)$ & $99.64(3)$ & $93.90(3)$ & $112.34(4)$ \\
$13.63(5)$ & $1150(4)$ & $10.88(2)$ & $10.64(2)$ & $11.031(2)$ & $99.46(2)$ & $95.31(2)$ & $112.0(2)$ \\
$10.80(5)^{*}$ & $1186(5)$ & $11.00(2)$ & $10.74(2)$ & $11.14(3)$ & $100.0(2)$ & $94.8(2)$ & $112.1(2)$ \\
$8.29(5)^{*}$ & $1211(7)$ & $11.04(4)$ & $10.85(4)$ & $11.24(3)$ & $99.9(3)$ & $94.9(3)$ & $112.3(3)$ \\
\hline
\end{tabular}


Table 7: Mg1-O bond distances (in $\AA$ ), based on the structure refinements of kurnakovite at high pressure. Volumes of $\mathrm{Mg} 1$ - and B-coordination polyhedra (in $\AA^{3}$; calculated using the routine implemented in the software Vesta [50]), based on the structure refinements at high pressure.

581

\begin{tabular}{llllllllll}
\hline$P(\mathrm{GPa})$ & 0.0001 & $1.07(5)$ & $1.83(5)$ & $3.21(5)$ & $4.43(5)$ & $5.35(5)$ & $6.54(5)$ & $8.08(5)$ & $9.23(5)$ \\
\hline $\mathrm{Mg} 1-\mathrm{O} 1$ & $1.996(11)$ & $1.987(11)$ & $1.986(11)$ & $2.018(13)$ & $1.985(12)$ & $1.993(12)$ & $1.952(13)$ & $1.971(11)$ & $1.969(12)$ \\
$\mathrm{Mg} 1-\mathrm{O} 2$ & $2.085(6)$ & $2.068(6)$ & $2.069(6)$ & $2.053(7)$ & $2.053(6)$ & $2.036(7)$ & $2.044(7)$ & $2.032(6)$ & $2.029(7)$ \\
$\mathrm{Mg} 1-\mathrm{O} 3$ & $2.002(11)$ & $2.026(11)$ & $2.020(10)$ & $1.980(10)$ & $1.986(10)$ & $1.957(11)$ & $1.960(10)$ & $1.949(11)$ & $1.933(11)$ \\
$\mathrm{Mg} 1-\mathrm{O} 4$ & $2.139(5)$ & $2.121(5)$ & $2.118(5)$ & $2.121(6)$ & $2.118(5)$ & $2.108(5)$ & $2.104(5)$ & $2.108(5)$ & $2.101(5)$ \\
$\mathrm{Mg} 1-\mathrm{O} 5$ & $2.084(7)$ & $2.067(6)$ & $2.057(6)$ & $2.046(8)$ & $2.027(7)$ & $2.024(7)$ & $2.003(7)$ & $1.991(6)$ & $1.982(7)$ \\
$\mathrm{Mg} 1-\mathrm{O} 6$ & $2.123(7)$ & $2.104(6)$ & $2.096(6)$ & $2.089(8)$ & $2.065(7)$ & $2.068(7)$ & $2.046(7)$ & $2.039(6)$ & $2.025(7)$ \\
$V_{\mathrm{Mg} 1}$ & $11.78(6)$ & $11.63(6)$ & $11.55(6)$ & $11.44(6)$ & $11.22(6)$ & $11.09(6)$ & $10.87(6)$ & $10.81(5)$ & $10.66(6)$ \\
$V_{\mathrm{B} 1}$ & $1.639(6)$ & $1.653(6)$ & $1.651(6)$ & $1.627(7)$ & $1.623(6)$ & $1.601(5)$ & $1.615(6)$ & $1.584(5)$ & $1.594(5)$ \\
$V_{\mathrm{B} 2}$ & $1.650(8)$ & $1.629(8)$ & $1.616(8)$ & $1.601(9)$ & $1.574(8)$ & $1.597(8)$ & $1.574(8)$ & $1.584(7)$ & $1.586(8)$ \\
\hline
\end{tabular}


616 Table 8: Two relevant angles $\left(\right.$ in $^{\circ}$ ) based on the structure refinements of kurnakovite at high 617 pressure.

618

619

620

621

622

623

624

625

626

627

628

629

630

631

632

633

634

635

636

637

638

639

640

641

642

643

644

645

646

647

648

649

650

651

652

653

654

655

656

657

658

659

660

661

662

663

664

665

\begin{tabular}{ccc}
\hline$P(\mathrm{GPa})$ & $\mathrm{B} 1-\mathrm{Mg} 1-\mathrm{B} 1\left(^{\circ}\right)$ & $\mathrm{O} 12-\mathrm{O} 12-\mathrm{O} 12\left(^{\circ}\right)$ \\
\hline 0.0001 & $147.7(6)$ & $164.5(6)$ \\
$1.07(5)$ & $147.9(5)$ & $162.9(6)$ \\
$1.83(5)$ & $148.0(5)$ & $160.9(6)$ \\
$3.21(5)$ & $148.5(6)$ & $157.7(3)$ \\
$4.43(5)$ & $148.8(6)$ & $156.4(2)$ \\
$5.35(5)$ & $147.6(5)$ & $154.5(5)$ \\
$6.54(5)$ & $148.8(6)$ & $152.9(5)$ \\
$8.08(5)$ & $149.2(6)$ & $151.2(4)$ \\
$9.23(5)$ & $149.2(5)$ & $150.1(5)$ \\
\hline
\end{tabular}


666

667
Fig. 1

a
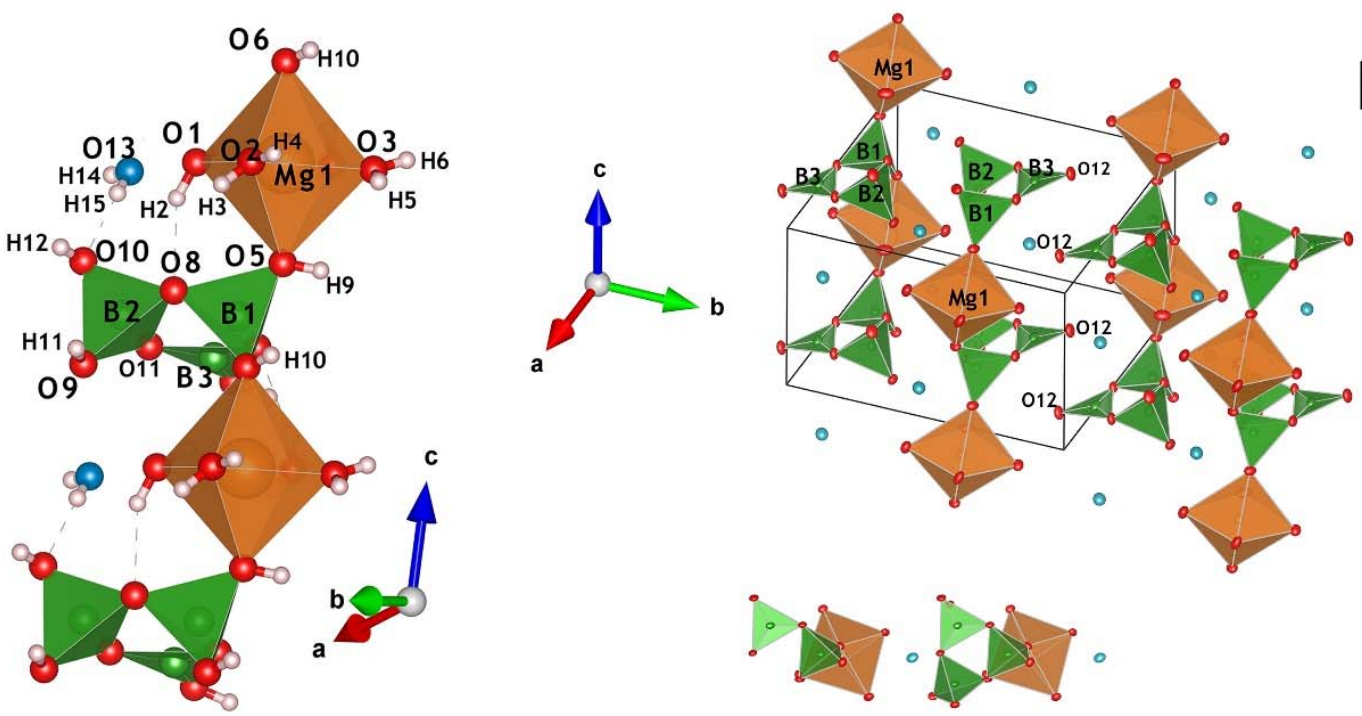

C

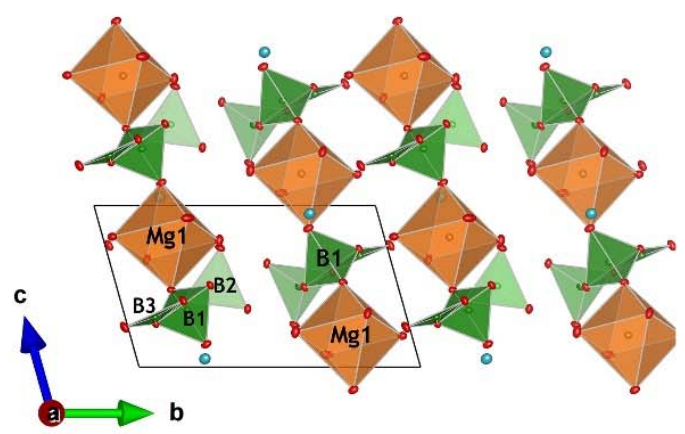

b
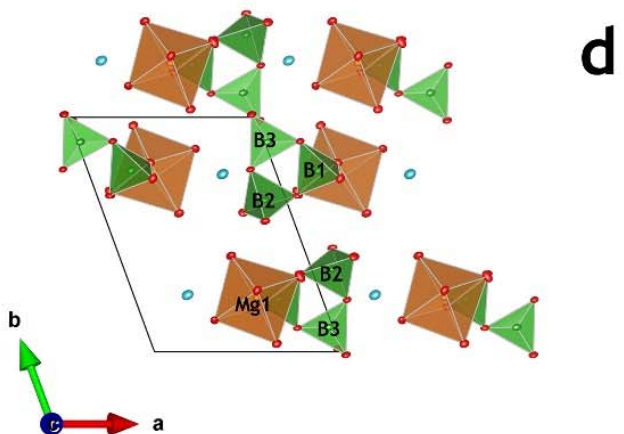
691

692

693

a

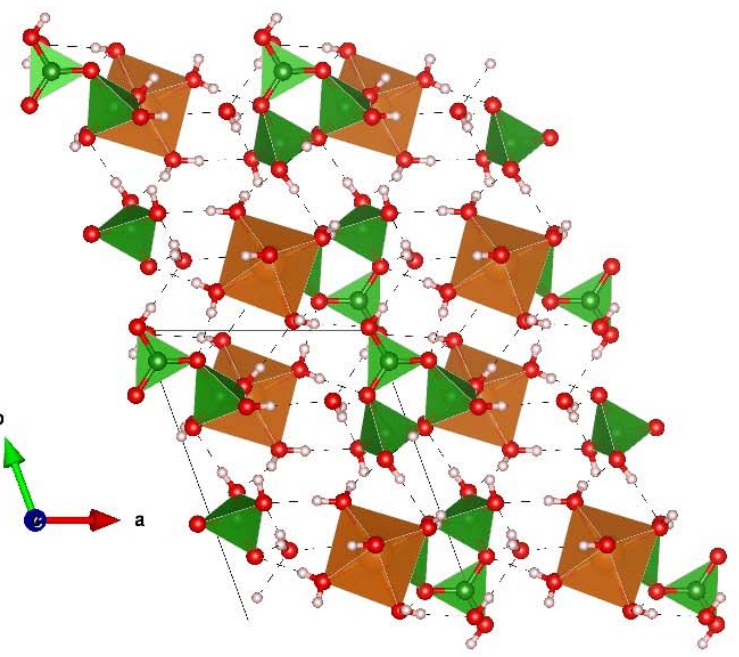

b

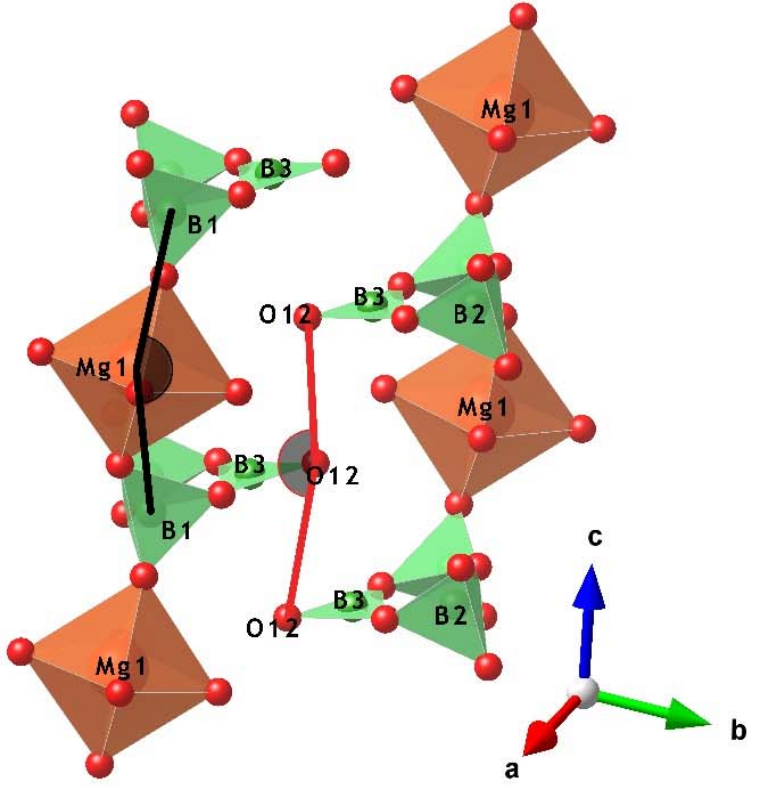

694

695

696

697

698

699

700

701

702

703

704

705

706

707

708

709

710

711

712

713

714

715

716

717

718

719

720

721

722

723

724 
Fig. 3

a

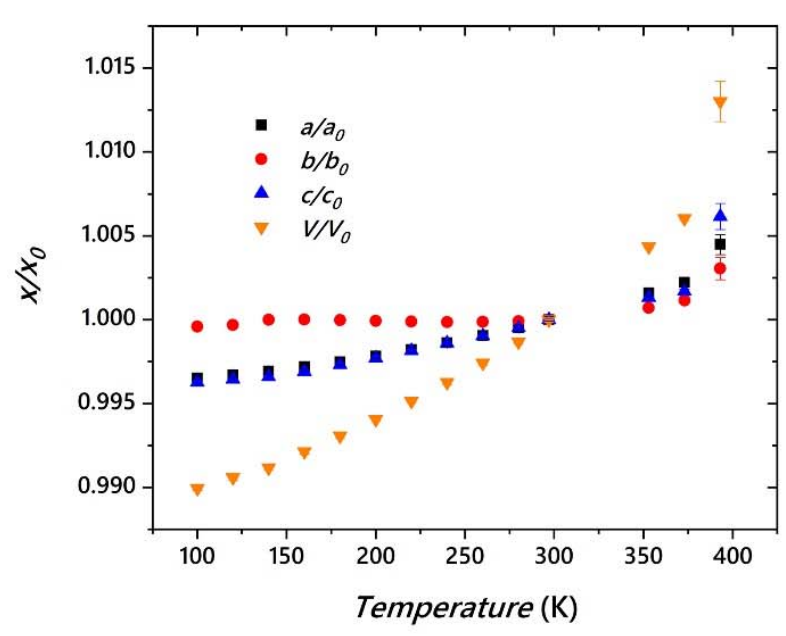

727

728

729

730

731

732

733

734

735

736

737

738

739

740

741

742

743

744

745

746

747

748

749

750

751

752

753

754

755

756

757

758

759

Fig. 4

C b

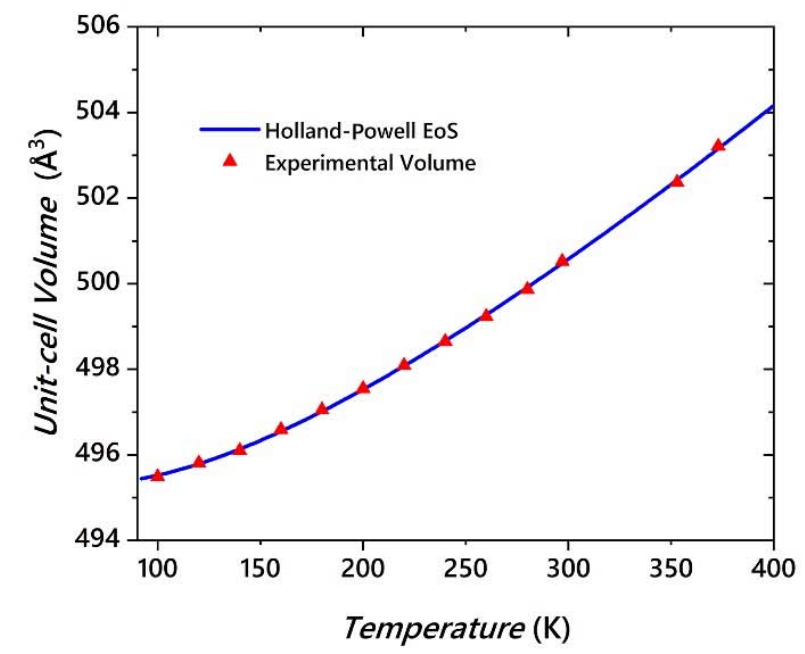

b
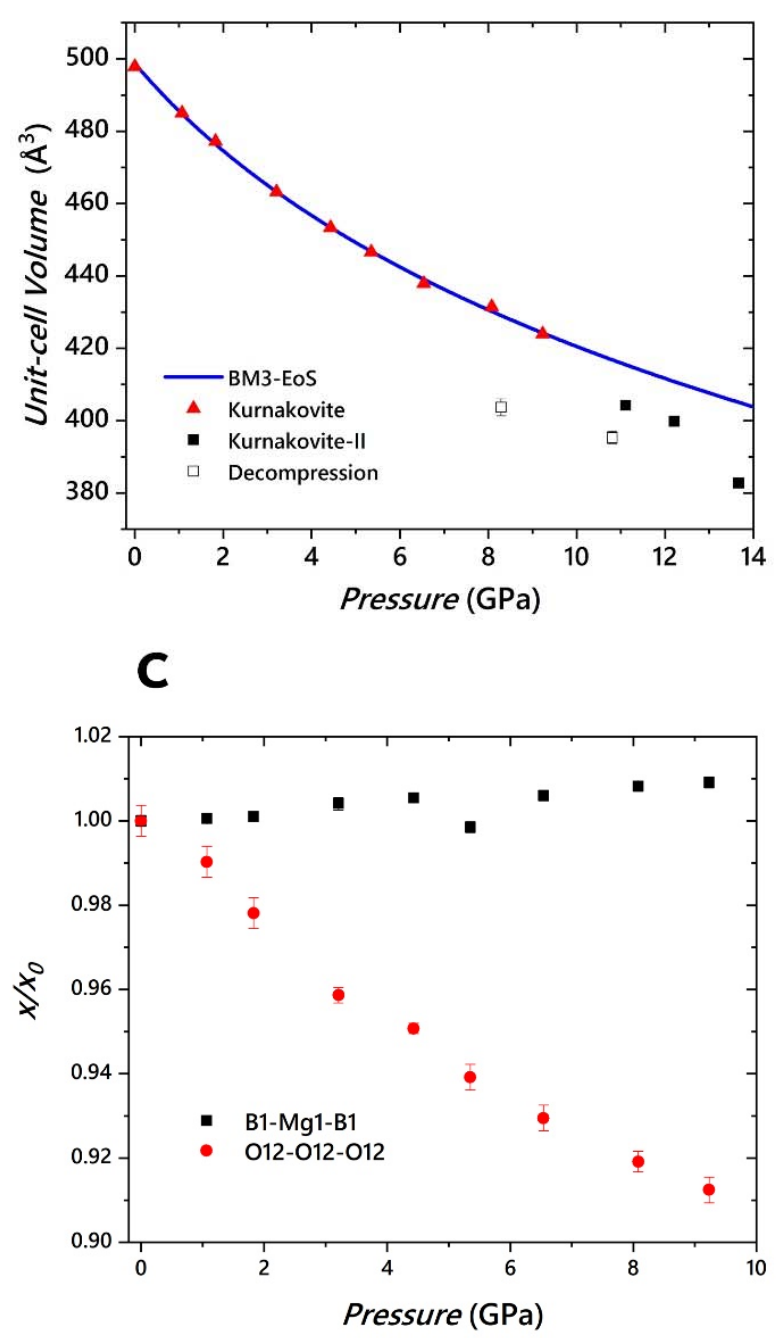

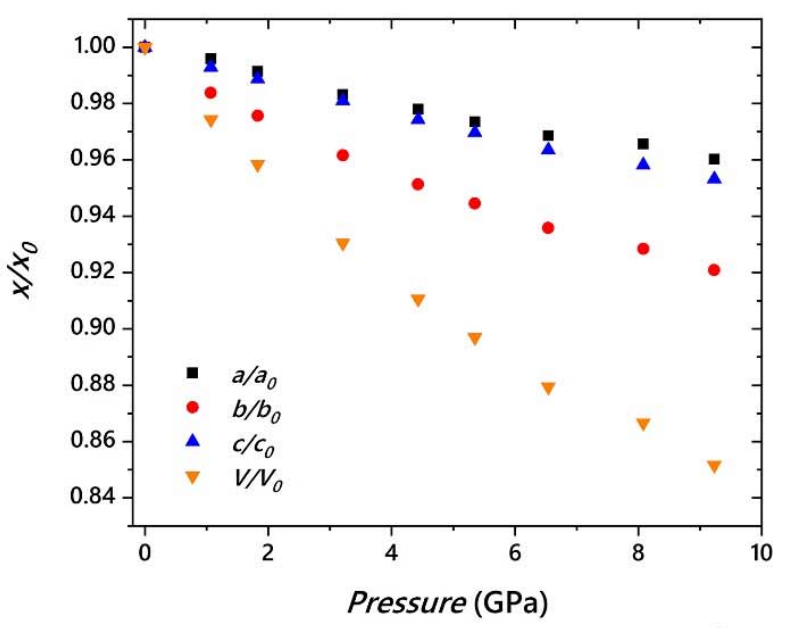

d

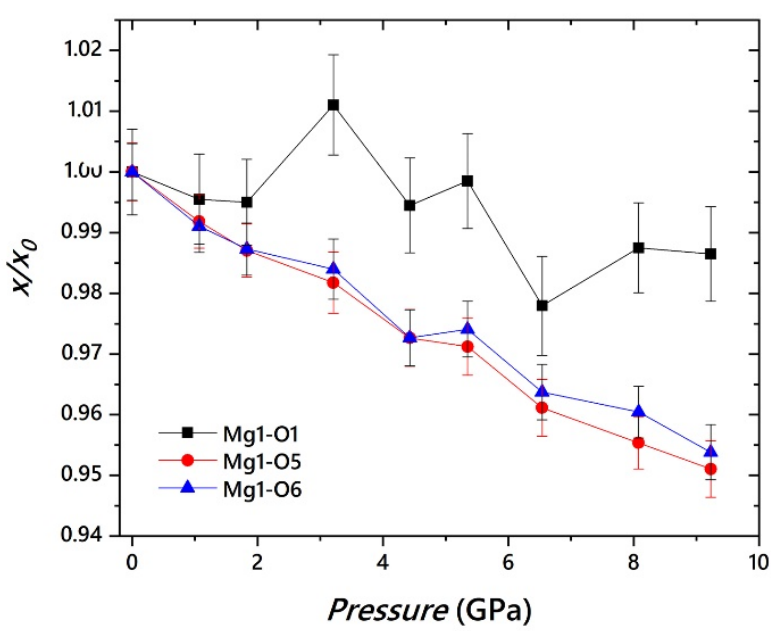


Fig. 5

a

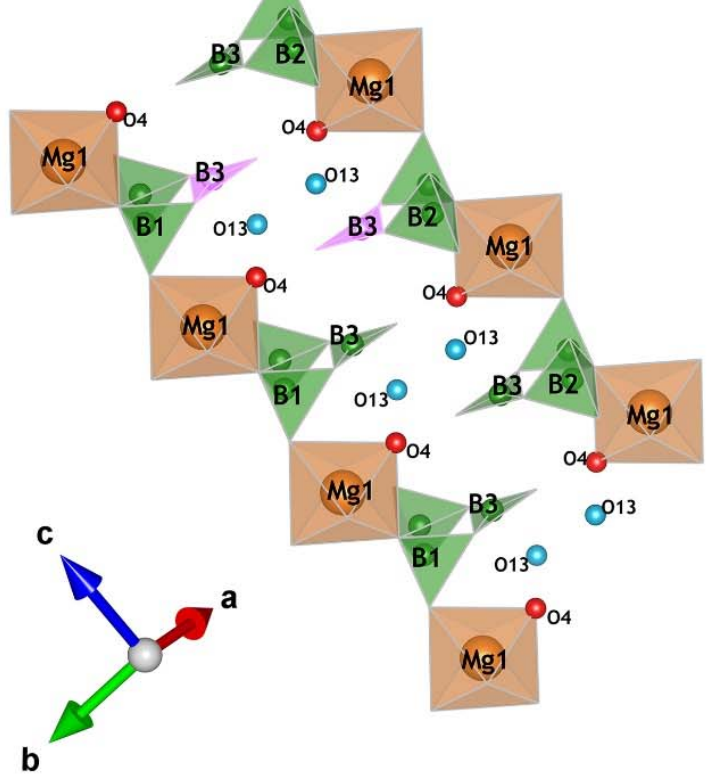

C

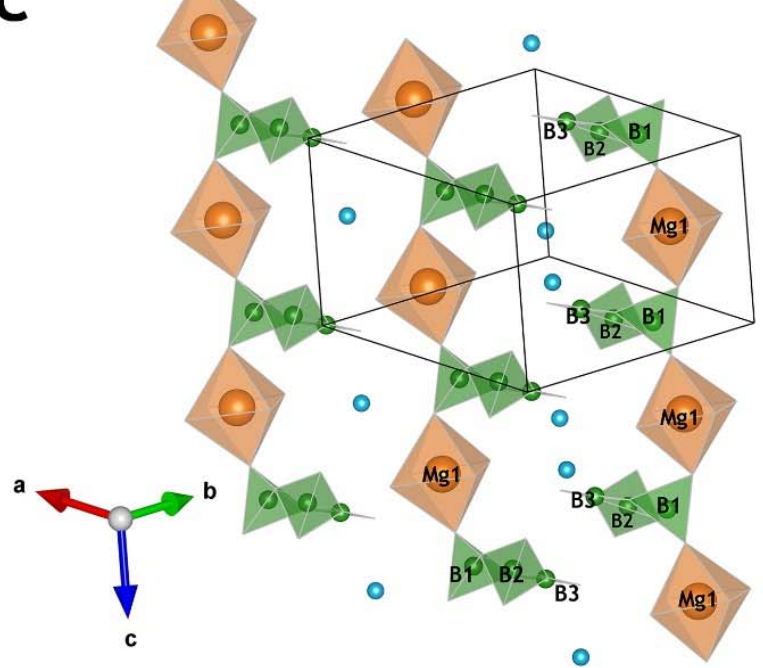

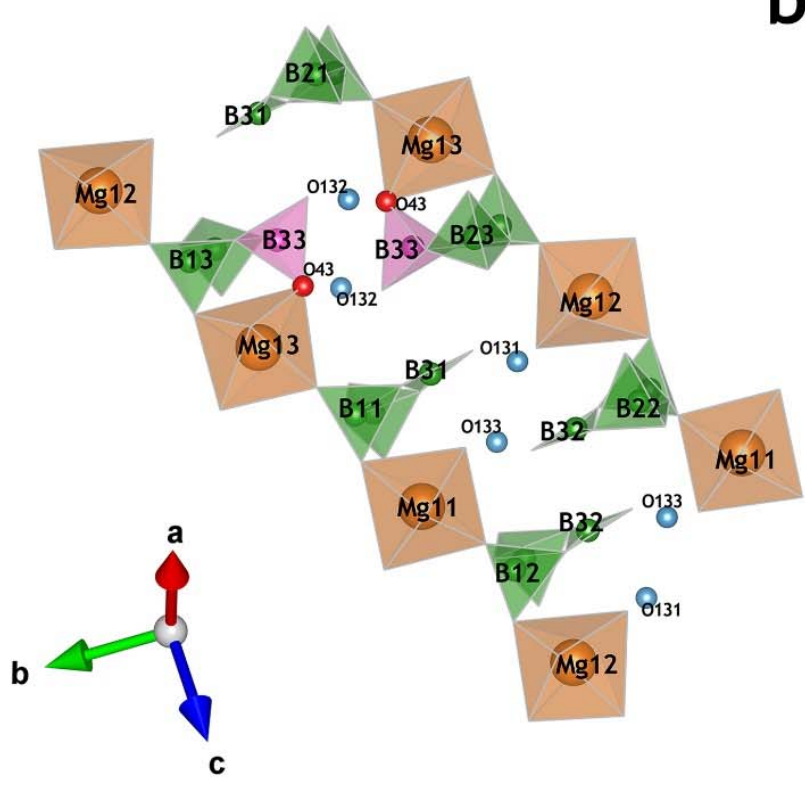

b

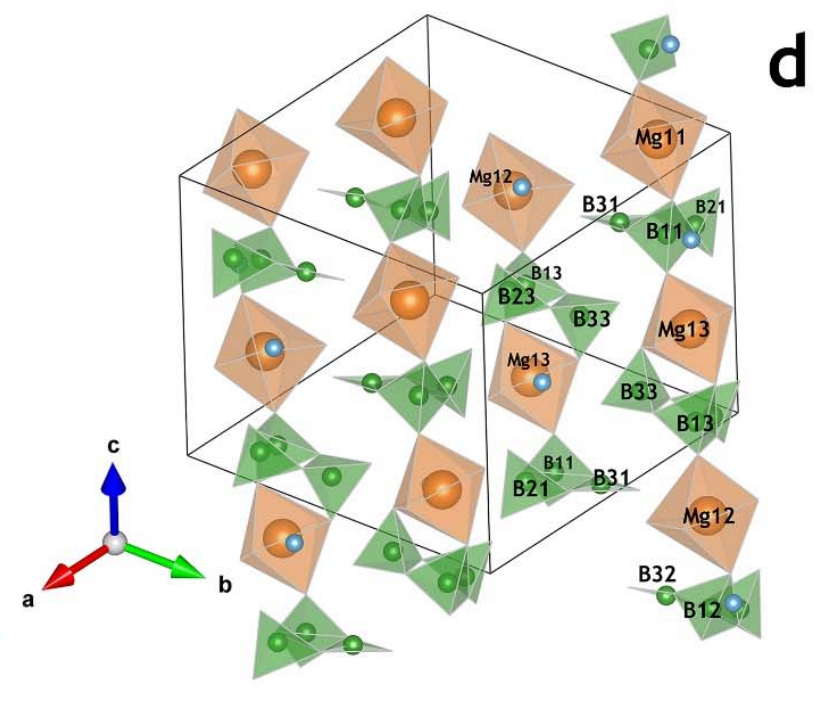


778

779

780

781

782

783

784

785

786 